\title{
Sequence stratigraphy and platform to basin margin facies transition of the Lower Cretaceous Dariyan Formation (northeastern Arabian Plate, Zagros fold-thrust belt, Iran)
}

\author{
Seyed Mohammad Ali Moosavizadeh, Asadollah Mahboubl, Reza MoussaVi-Harami, \\ MOHAMMAD ALI KAVOOSI \& FELIX SCHLAGINTWEIT
}

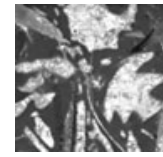

\begin{abstract}
The Lower Cretaceous (Aptian-Albian) Dariyan Formation (northeastern Arabian Plate, Iran) represents the youngest sediments of the Khami group in the Zagros fold belt. This study is based on six sections located in the Izeh Zone and Interior Fars Province documenting transition from platform to a basin margin facies. Three assemblage zones based on benthic foraminifers have been identified and provide an early Aptian-early Albian age. Petrographic and microfacies analyses characterize thirteen carbonate microfacies and two mud rock lithofacies-types. The vertical and lateral facies variations observed in this study for the Dariyan Formation are in agreement with a depositional environment going from a homoclinal carbonate ramp to margin of intra-shelf basin type. Based on the identification of three sequence boundaries (SB), the Dariyan Formation sediments has been divided into three $2^{\text {nd }}$-order depositional sequences which encompasses six and five $3^{\text {rd }}$-order sequences in the margin of intra-shelf basin and the shallow platform settings, respectively. The early Aptian sea-level rise led to the extension of the carbonate platform and deposition of pelagic facies as a maximum flooding surface on margin of intra-shelf basin. In the late Aptian highstand phase, the platform was exposed as a result of glacio-eustatic mechanisms, whereas sediments continued to accumulate in the margin of intra-shelf basin. This study supports the general paleogeography of the studied area documented by previous studies and provides better insight to the interpretation of the evolution in this area and other similar basins. - Key words: Dariyan Formation, Aptian, Arabian Plate, Zagros, sequence stratigraphy.
\end{abstract}

Moosavizadeh, S.M.A., Mahboubi, A., Moussavi-Harami, R., Kavoosi, M.A. \& Schlagintweit, F. 2015. Sequence stratigraphy and platform to basin margin facies transition of the Lower Cretaceous Dariyan Formation (northeastern Arabian Plate, Zagros fold-thrust belt, Iran). Bulletin of Geosciences 90(1), 145-172 (19 figures, supplementary data). Czech Geological Survey, Prague. ISSN 1214-1119. Manuscript received February 2, 2013; accepted in revised form October 27, 2013; published online January 6, 2015; issued January 26, 2015.

Seyed Mohammad Ali Moosavizadeh (corresponding author), Asadollah Mahboubi \& Reza Moussavi-Harami, Department of Geology, Faculty of Sciences, Ferdowsi University of Mashhad, Iran; Moosavizaadeh@yahoo.com • Mohammad Ali Kavoosi, National Iranian Oil Company, Exploration Directorate, Tehran, Iran • Felix Schlagintweit, Lerchenauerstr. 167, 80935 München, Germany

The Aptian-Albian Dariyan Formation (see Schroeder et al. 2010) represents a carbonate reservoir in the southwestern part of Iran (e.g. Habibi et al. 1994, unpublished report). This formation conformably over- and underlies the Gadvan and Kazhdumi formations (Fig. 1). The Dariyan Formation was deposited at the northeastern edge of the Arabian Plate, itself part of the SW passive margin of the Neo-Tethys Ocean (Fig. 2; James \& Wynd 1965, Motiei 1993, Ziegler 2001, Alavi 2004). During the Early Cretaceous, the NE part of Arabian Plate was covered by a widespread shallow carbonate platform with some intra-shelf basins especially in the southeastern part (James \& Wynd 1965, Masse 1993, Motiei 1993, Ziegler 2001, Sharland et al. 2001, Alavi 2004). Econo- mically, these intra-shelf basins are important because they provide the source rocks to the petroleum systems (e.g. Droste 1990, Sharland et al. 2001, van Buchem et al. 2010, Razin et al. 2010). The heterogeneity of the sedimentary facies (i.e. carbonate and siliciclastic) due to the presence of these intra-shelf basins is one of the main parameter controlling the distribution and quality of the reservoirs. Thus, characterizing the sedimentary distribution and geometry within these settings is of primary importance in the understanding the formation of the oil reservoirs. Two main intra-shelf basins, the Kazhdumi and Bab basins, have been often described and studied within the Arabian Plate (Sharland et al. 2001, Ziegler 2001, Al-Gamdi 2006, van Buchem et al. 2010). In this study, 


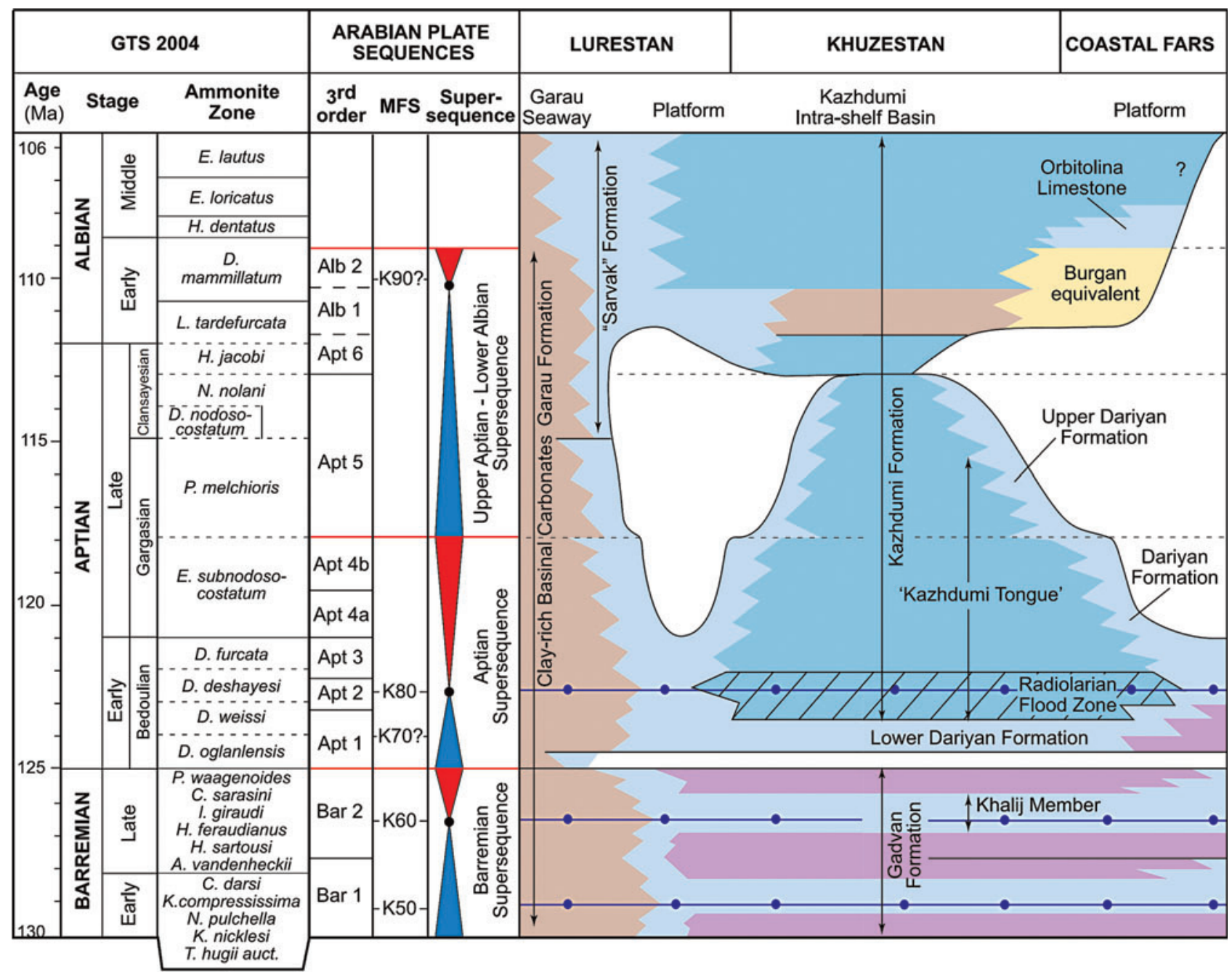

Figure 1. Aptian-Albian lithostratigraphy of the Zagros fold-trust belt (ZFTB). The Dariyan Formation is underlying the Gadvan Formation and overlying the Kazhdumi Formation (simplified after van Buchem et al. 2010).

we focused on the Early Cretaceous deposits of the Kazhdumi Basin (SW Iran, Fars), which generated the oil for most of the Sarvak and Asmari reservoirs in SW Iran (e.g. Bordenave \& Burwood 1990). The general paleogeography of this basin has been well studied (James \& Wynd 1965, Setudehnia 1976, Bordenave \& Burwood 1990). More recently, a detailed sequence stratigraphic analysis has been provided by van Buchem et al. (2010) on the Kazhdumi Basin. In their model, the authors explained the lateral facies distribution and sedimentation pattern as mainly controlled by the relative contribution of structural control and eustatic sea level variations. Notably, they suggested that the Kazerun fault system was activated in the early Aptian, which, associated with the eustatic sea level rise, was responsible for the creation of the Kazhdumi Basin. However, this model was based on a limited number of outcrops.

Here we investigate the lateral facies evolution, the thickness variations and depositional geometries along the eastern margin of the Kazhdumi Basin in the Interior Fars
Province, by studying the platform-basin margin transition that covers the Kazerun fault system. One of the key challenges is to provide a time framework to constrain the lateral facies variations. In this study we used the recently published orbitolinids zonation scheme defined for the Eastern Arabian Plate, and calibrated to a number of Iranian outcrop sections (Schroeder et al. 2010). This zonation scheme was calibrated using both ammonite zones and stable carbon isotope variations. We distinguished three assemblage zones (A, B and C) that allowed us to consider the expansion of late Aptian top-platform exposure based on sequence stratigraphic correlation between platform and margin of intra-shelf basin settings.

\section{Geological setting}

The Zagros fold-thrust belt is part of the Alpine compression system (Berberian \& King 1981, Alavi 2004). The 
Zagros area corresponds to one of the most resource-prolific fold-thrust belt system in the world (James \& Wynd 1965, Berberian \& King 1981, Motiei 1993, Alavi 2004). According to geological evidences, as the Neo-Tethys Ocean widened, the Zagros region was part of a large passive margin situated at the northeastern edge of the Arabian Plate (Alavi 2007, Navabpour et al. 2010, Heydari 2008). Three parallel zones can be distinguished in the Zagros mountain chain (Fig. 3B): the Uremiah-Dokhtar magmatic assemblage (UDMA; Alavi 1980, 1994), the Zagros Imbricate Zone (ZIZ) and the Zagros Fold-Thrust Belt (ZFTB; Alavi 2007). The study area is located in the ZFTB. This belt is subdivided into different structural zones including the Interior Fars, the Coastal Fars, the Izeh, the Dezful Embayment and the Lurestan zones. They are separated by strike slip faults known as Balarud, Hendijan and Kazerun faults (Fig. 3D; Berberian \& King 1981). The biostratigraphy of the Gadvan, Dariyan and Kazhdumi formations, first established by Wynd (1965, unpublished report), has been recently revised by Schroeder et al. (2010). The new biozonation has been defined in the eastern part of the Arabian Plate using orbitolinids and showed that the Dariyan Formation was deposited during the early Aptian (Coastal Fars) to the early Albian (Izeh Zone). This age model is supported by planktonic foraminifer, ammonite and stable carbone isotope data in the Kazhdumi Basin,

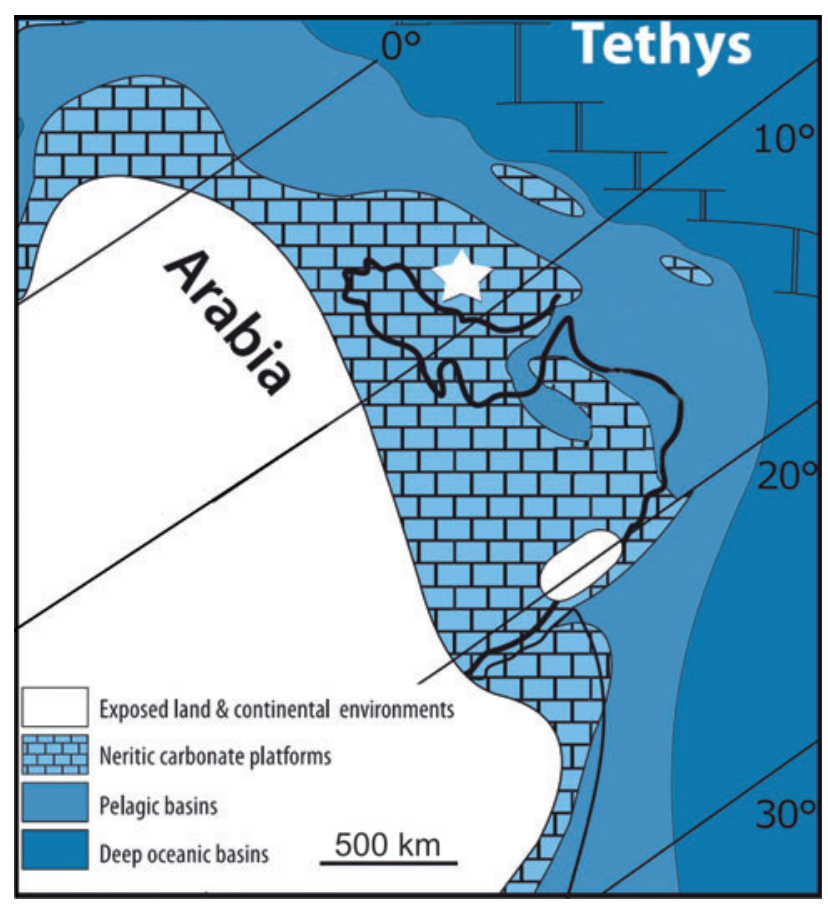

Figure 2. General paleogeographic map of the Arabian Plate during the Aptian (simplified after Huck et al. 2010). The solid line show present day position of the gulf of Fars and the study area is shown by the white asterisk.
Figure 3. Maps of the study area. - A - general map of the Middle East (modified after Sharland et al. 2001. • B - the eight geologic provinces of Iran, the rectangle indicates the position of the ZFTB in SW Iran (modified after Vaziri-Moghaddam et al. 2006). $\bullet$ C - subdivision of ZFTB (adapted from Sherkati \& Letouzey 2004), the hatched rectangle shows the study area. - D - paleogeographic map of ZFTB during the Aptian, the selected sections are shown by the solid circles: 1 - Kuh-e-Fahliyan; 2 - KuzehKuh; 3 - Kuh-e-Sefid; 4 - Rahmat-Abad; 5 - Kuh-e-Gadvan; 6 - Khaneh-Kat. Simplified after van Buchem et al. (2010).

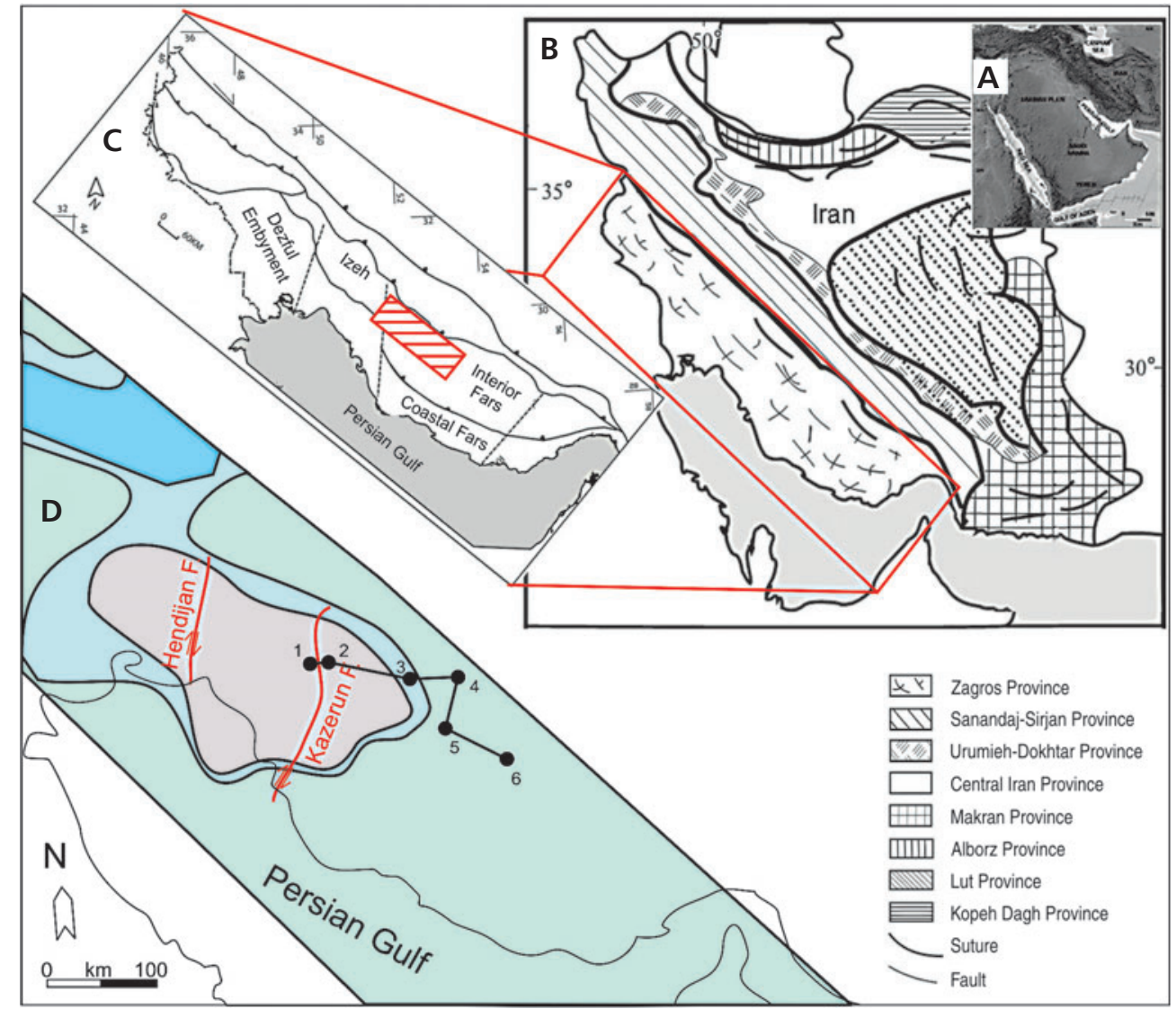


a) Restricted platform top facies, small benthic foraminifers and green algae dominated wackestone to packstone

b) Platform top facies, ooid and bioclast dominated grainstone, high energy facies

c) Platform top facies, orbitolinid dominated wackestone to packstone

d) Platform top facies, bivalve and bioclast dominated wackestone to packstone

e) Intra-shelf basin facies, radiolar and planktonic foraminifers wackestone to packstone

f) Intra-shelf basin sale and marl

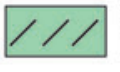

Assemblage A - Assemblage B Early Aptian
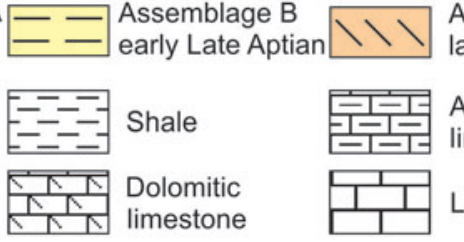

Assemblage $\mathrm{C}$ late Late Aptian-Early Albian

Alb: Albian

Apt: Aptian

Bar: Barremian

Gad: Gadvan Formation TST: Transgressive System Tract
Bioclast

Radiolar

Echinoid

Green algae

Sponge Spicule

Discoidal orbitolinid

Planktonic foraminifer

Small benthic foraminifer

FS: Flooding surface

SB: Sequence boundary

MFS: Maximum flooding surface
LEGEND

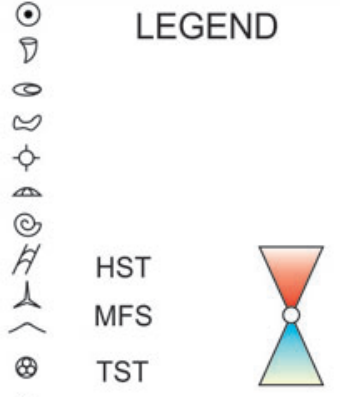

$-\cdot \cdot \cdot \cdot-\cdot$

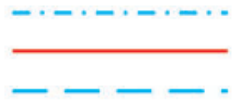

\begin{tabular}{|c|c|c|c|c|c|}
\hline & Chert & & Shale & 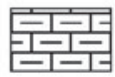 & $\begin{array}{l}\text { Argillaceous } \\
\text { limestone }\end{array}$ \\
\hline & Marl & ה & $\begin{array}{l}\text { Dolomitic } \\
\text { limestone }\end{array}$ & & Limestone \\
\hline
\end{tabular}

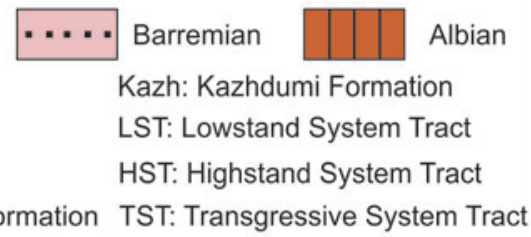

Figure 4. Legend of colour codes and symbols used in graphic pictures.

Coastal Fars and Lurestan Zone (Vincent et al. 2010). Moosavizadeh et al. (2013) confirmed this age in Kuh-e-Sefid section based on $\mathrm{C}$-isotope stratigraphic data. Here we used the orbitolinid biozonation to better constrain the age along the studied platform-basin margin transect.

\section{Methods}

Six outcrops of the Dariyan Formation (Fig. 3D) have been selected along a platform-basin transect with the sections of Kuh-e-Fahliyan, Kuzeh-Kuh, Kuh-e-Sefid, RahmatAbad, Kuh-e-Gadvan and Khaneh-Kat. About 1000 samples in total were collected and investigated and their thin sections were studied. The classifications of Dunham (1962) and Embry \& Klovan (1971) were used for facies description, and the Dickson (1966) method was used for distinguishing calcite and dolomite. Microfacies analysis was carried out using the standard models of Wilson (1975) and Flügel (2010). Interpretation of depositional environment has been based on Read (1985) and Burchette \& Wright (1992). The recognition of $3^{\text {rd }}$-order depositional sequences follows the definition provided by van Wagoner et al. (1988, 1990), Vail et al. (1991), Catuneanu (2006) and Catuneanu et al. (2009). The biostratigraphy is mainly based on orbitolinids zonations (Schroeder et al. 2010).

\section{Lithostratigraphy}

The Dariyan Formation was formerly known as the "Orbitolina Limestone" or "Aptian-Albian Limestone". Its ac- tual name is derived the name of Dariyan, the village close to the type locality (James \& Wynd 1965). In the Kuh-e-Fahliyan, Kuzeh-Kuh and Kuh-e-Sefid sections the Dariyan Formation can be divided into three parts based on the presence of a marly interval, the so called "Kazhdumi Tongue" (Sedaghati 1982; Figs 5, 7). This marly interval disappears towards the platform and is not observed in the other three shallower sections (Figs 6, 8). In the first group of sections, the lower Dariyan consists of medium- to thin-bedded grey, partly argillaceous limestones with marl-limestone couplets. This is followed by an alternation of thin-bedded pelagic limestones, argillaceous laminated limestones and thin-bedded $(2-15 \mathrm{~cm})$ black cherts (Fig. 9A). In Kuh-e-Sefid section this part contains rather high amounts of organic matter and is characterized by the deposition of black limestones (Fig. 9B) and dark shales (Fig. 9C). The macrofauna in the lower Dariyan is represented mainly by bivalves, echinoids (Fig. 9D) and ammonites (mostly outer mold) (Fig. 9E). Chert nodules (up to $30 \mathrm{~cm}$ ) containing ammonites, bioturbation and iron-crusted surface on the top surface of pelagic interval (Fig. 9F) are additional features of lower Dariyan. The "Kazhdumi Tongue" is mainly defined by grey to dark grey shale with alternation of marls and thin argillaceous limestones (Fig. 10A). This interval is not observed along the sections of Rahmat-Abad, Kuh-e-Gadvan and KhanehKat. The upper Dariyan is generally composed of mediumto thick-bedded grey limestones containing a large amount of conical and discoidal orbitolinids (Fig. 10B) and variable amounts of bivalves, echinoids and gastropods. Some parts also contain corals (Fig. 10C). Upward-thickening cycles and beds with intense bioturbation marked by 


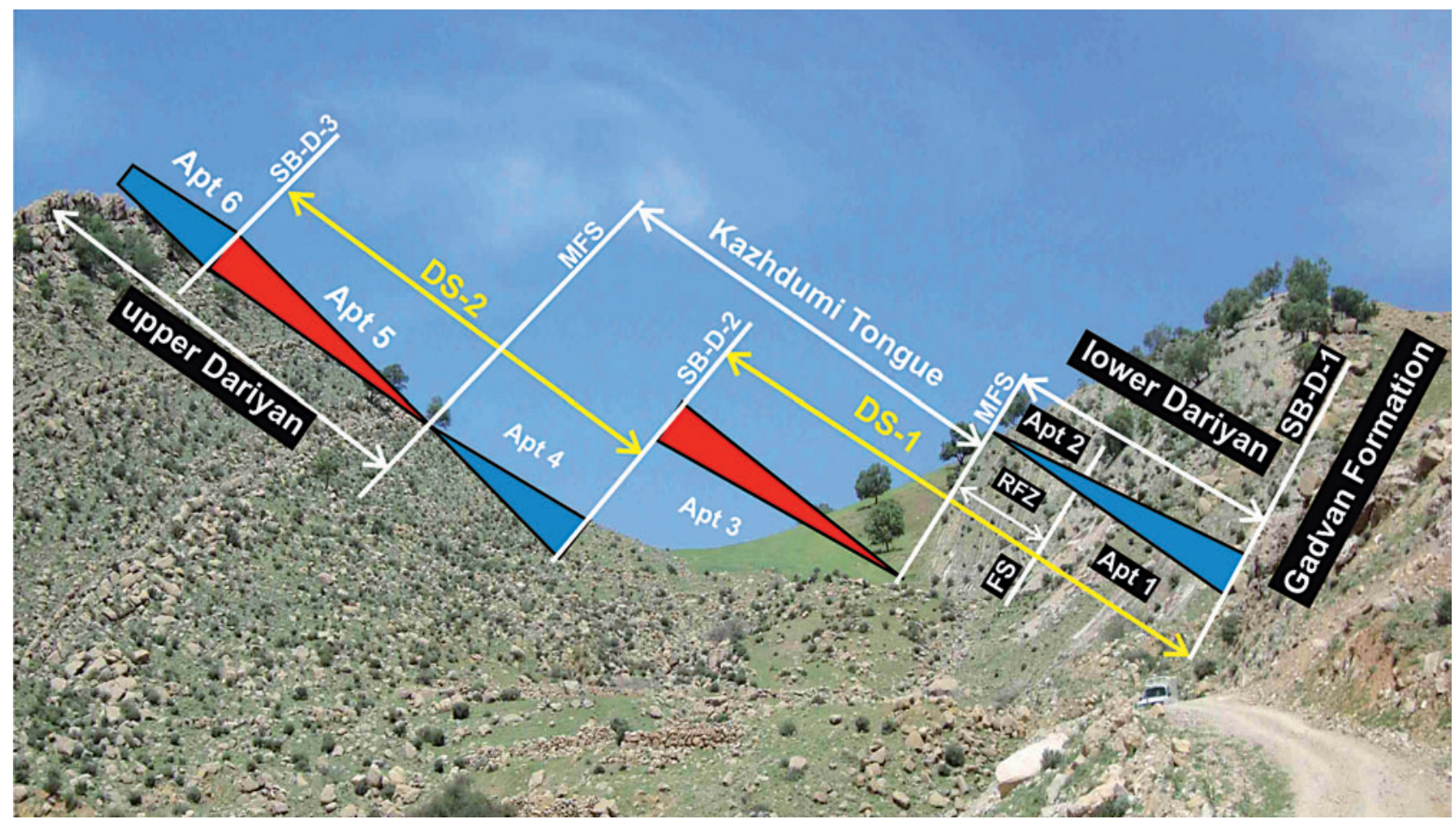

Figure 5. Field aspects of the Dariyan Formation at Kuzeh-Kuh (intra-shelf basin setting). The lower and upper Dariyan, Kazhdumi Tongue and sequence stratigraphic subdivisions of the formation are indicated on the log (see Fig. 4 for the legend).

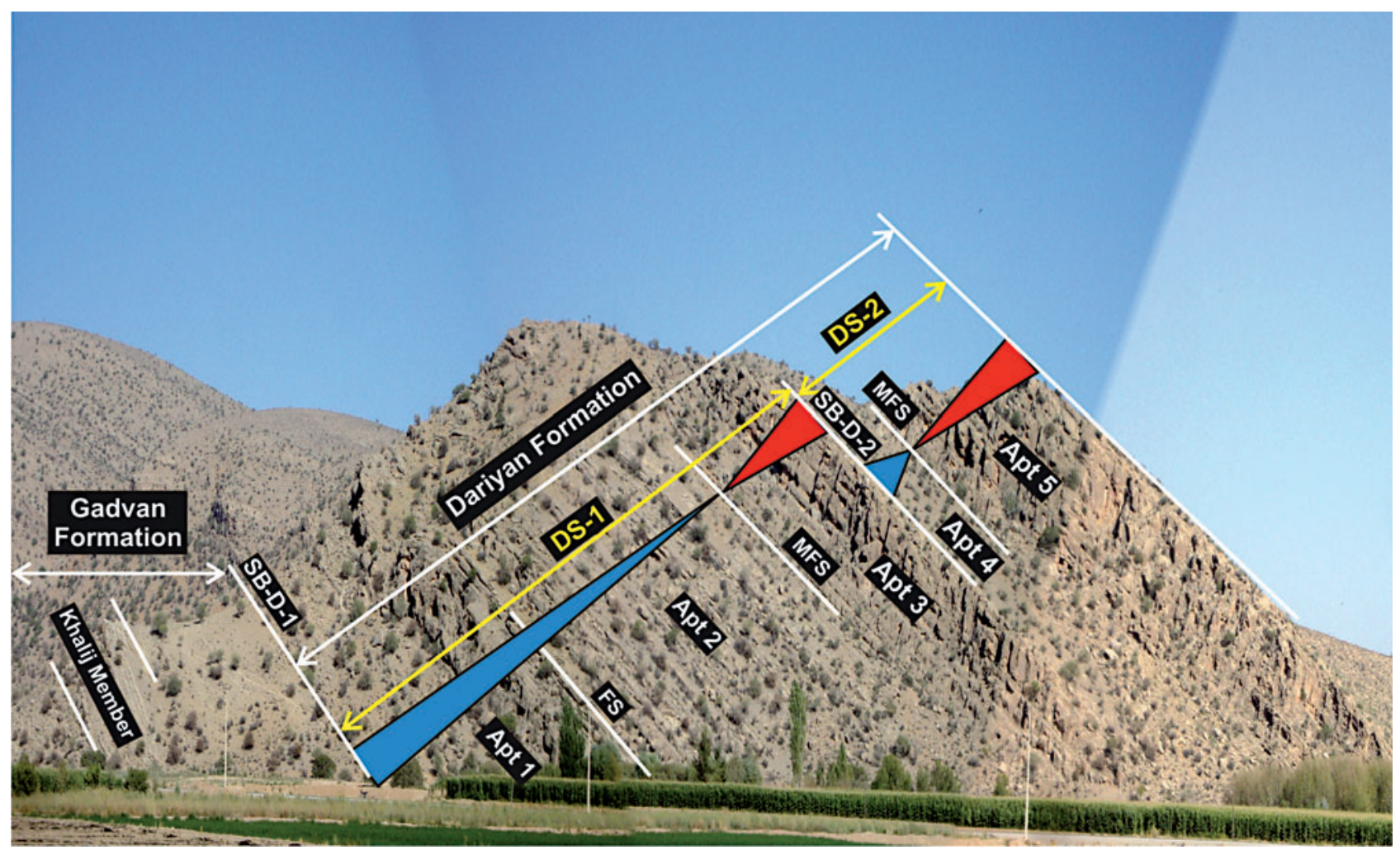

Figure 6. Field aspects of the Dariyan Formation along the Rahmat-Abad section (top-platform setting). The sequence stratigraphic subdivisions of the formation are shown by the blue and red triangles (see Fig. 4 for the legend). 


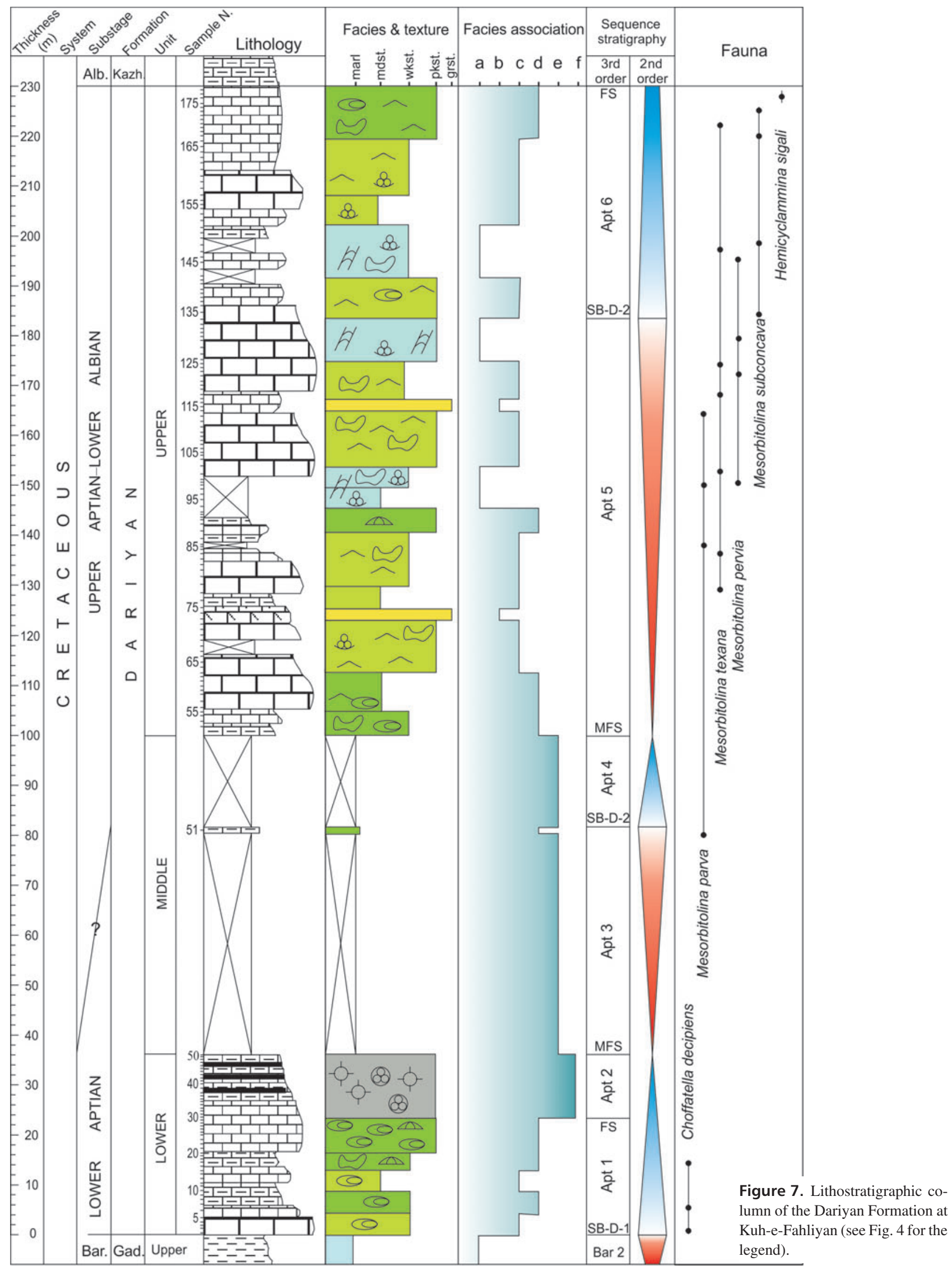




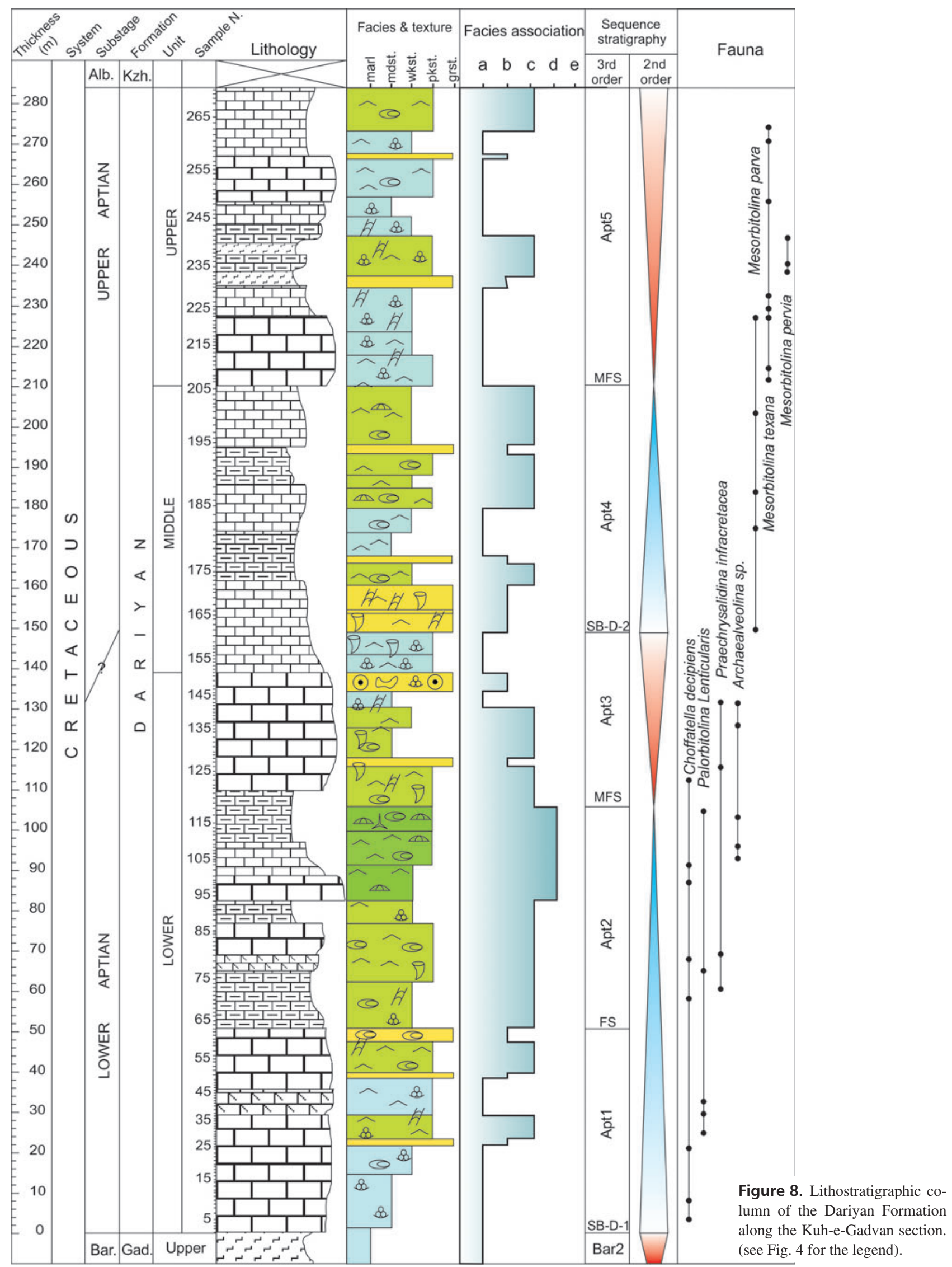


limonitic limestone are also observed in this part. The boundary with Kazhdumi Formation towards the top of the sections is sharp and, at Kuh-e-Fahliyan, represented by highly bioturbated grey limestones (Fig. 10D). A largescale sedimentary structure such as sigmoidal clinoform has been distinguished in the upper Dariyan at Kuh-e-Sivand (Fig. 11). This section has been studied by Safari (2007) and Nazariyan (2007) without mentioning this sedimentary structure. Clinoform inclination and lateral thinning trends show that the sediments have been moved from East to West.

In the Rahmat-Abad, Kuh-e-Gadvan and Khaneh-Kat sections, the Dariyan Formation consists of medium to thick-bedded, partly argillaceous limestones (Figs 6, 8) with large amounts of orbitolinids. Rudists shells (Fig. 10E) are clearly visible in Kuh-e-Gadvan and Khaneh-Kat sections but cannot be observed in others. Cross-bedding, cross-lamination (Fig. 10F) and disperse small iron and chert nodules were observed in Kuh-e-Gadvan and Khaneh-Kat sections.

\section{Biostratigraphy}

During the Lower Cretaceous (Aptian), the benthic foraminifer assemblages in carbonate environments of Tethyan realm were dominated by orbitolinids (Simmons et al. 2000, Pittet et al. 2002, Schroeder et al. 2010). Ten different benthic foraminifers have been recognized in the Dariyan Formation: Archaealveolina sp., Praechrysalidina infracretacea Luperto Sinni, Choffatella decipiens (Schlumberger), Hemicyclammina sigali Maync, Palorbitolina lenticularis (Blumenbach), Palorbitolina ultima (Cherchi \& Schroeder), Mesorbitolina parva (Douglass), Mesorbitolina pervia (Douglass), Mesorbitolina texana (Roemer) and Mesorbitolina subconcava (Leymerie) (Fig. 12). According to the biozonation established by Schroeder et al. (2010) three different assemblages can be distinguished and defined as: assemblage A including Archaealveolina sp., Praechrysalidina infracretacea, Choffatella decipiens, Palorbitolina lenticularis and Palorbitolina ultima which characterizing the early Aptian, assemblage B including Mesorbitolina parva, Mesorbitolina pervia and Mesorbitolina texana giving an early-late Aptian age and assemblage $\mathrm{C}$ including Mesorbitolina texana, Mesorbitolina subconcava and Hemicyclammina sigali characterizing the late Late Aptian to early Albian. In the sections of Khaneh-Kat, Kuh-e-Gadvan and RahmatAbad, the benthic foraminifera record only allowed to define the first two assemblages. The occurrence of Mesorbitolina subconcava (Fig. 12L) and Hemicyclammina sigali (Fig. 12M) associated with the presence of Mesorbitolina texana (Fig. 12I, J) indicates late late Aptian to early Albian age (Simmons 1994, Schroeder et al. 2010). In sum- mary, the age of the Dariyan Formation along the studied sections provide an age ranging between the early Aptian to the early Albian.

\section{Microfacies analysis}

Based on the petrographic analysis and the description of thin sections, 13 microfacies (MF) and two lithofacies (LF) were recognized in the Dariyan Formation. These facies have grouped into four facies associations (A, B, C and D), which can be described as followed:

\section{Intra-shelf basin $(A)$}

\section{LF-type 1: Mudstone}

This facies is characterized by green to grey shale with radiolarids and planktonic foraminifers (globigerinelloids and hedbergellids) and in the Kuh-e-Sefid sections by high amount of organic matter (black shale in the lower Dariyan). In the field, this facies is subject to a high degree of weathering and it is mostly covered.

\section{LF-type 2: Marl}

The LF is defined by greenish to grey marl with relatively large amount of planktonic foraminifers. The presence of ostracods and horizontal lamination are also observed. This facies is mostly present in the Kazhdumi Tongue.

\section{MF-type 1: Radiolarian packstone/wackestone} (Fig. 13A)

Radiolarians $(\sim 50 \%)$ and planktonic bivalves $(\sim 10 \%)$ are the main components of this facies. The presence of globigerinelloids is also observed. The most important macrofauna of this facies is represented by outer molds of ammonites dispersed in a thin-bedded, cream-colored to white argillaceous limestone. In some cases, the matrix contains organic matter. In the Kuh-e-Sefid section, organic matter is mainly concentrated in black limestones (Fig. 9C) and shales.

\section{MF-type 2: Planktonic foraminifer packstone} (Fig. 13B)

This microfacies type is characterized by a relatively large amount of planktonic foraminifers (45\%; mainly globigerinelloids and hedbergellids). Other components such as filaments, radiolarians and sponge spicules are also present and the matrix contains organic matter (Fig. 9E). The intercalated thin-bedded black cherts show similar components (Fig. 13C, D) 

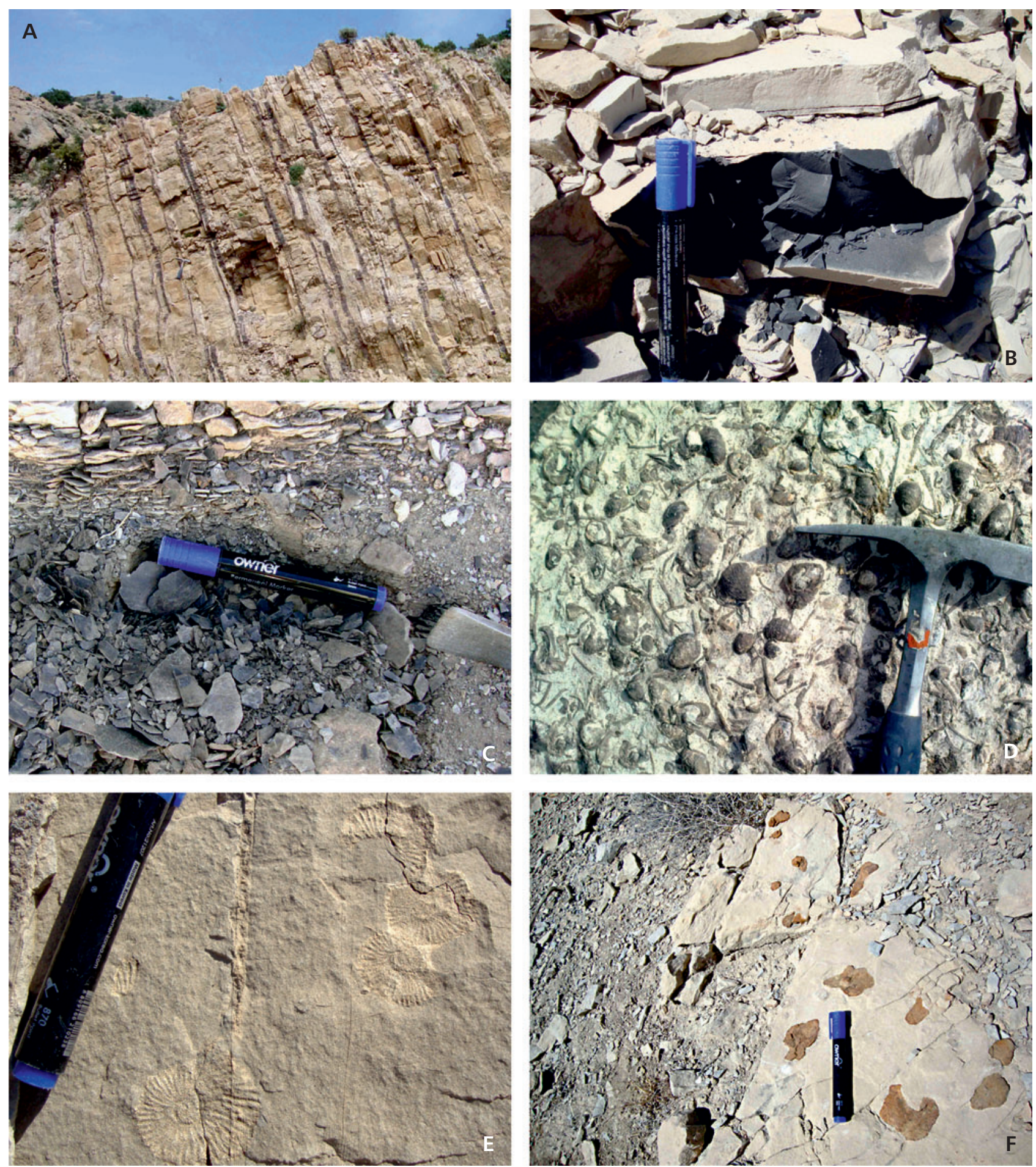

Figure 9. Field aspects of the Dariyan Formation. $\bullet$ A - alternation of pelagic limestone with thin-bedded black chert, at Kuzeh-Kuh, $35 \mathrm{~m}$. B - black limestone of the lower Dariyan Formation at Kuh-e-Sefid section, $43 \mathrm{~m} \cdot \bullet \mathrm{C}$-interbeds of black shale, lower Dariyan, in the Kuh-e-Sefid section, $40 \mathrm{~m}$. -D - bivalves (Exogyra) shells and crinoids on the surface of a shell bed, at Kuzeh-Kuh, $18 \mathrm{~m}$. $\bullet$ E - ammonites in pelagic limestone of the lower Dariyan Formation, in the Kuzeh-Kuh section, $37 \mathrm{~m}$. $\mathrm{F}$ - iron-crusted surface at the top surface of the lower Dariyan, at Kuh-e-Sefid, $50 \mathrm{~m}$. 


\section{MF-type 3: Planktonic foraminifer wackestone (Fig. 13E)}

Mud-supported facies is determined by medium- to thickbedded, dark grey limestone to argillaceous limestone. Planktonic foraminifers $(15 \%$, average size $0.1 \mathrm{~mm})$ are the main components. Peloids, sponge spicules and undeterminable bioclastic debris are of subordinate importance.

\section{Interpretation}

According to the presence of argillaceous limestones, horizontal lamination and lime-mud supported texture, these litho- and microfacies types have probably been deposited in a low energy environment (Bover-Arnal et al. 2009, Flügel 2010). Components such as radiolarians, planktonic foraminifers and sponge spicules indicate basinal setting, at least below the storm wave base (Bassi \& Nebelsick 2010, Payros et al. 2010, Gorican et al. 2012). Although radiolarian-rich sediments could be observed on continental margin or shallow marine platforms (e.g. Ellis \& Baumgartner 1995, Danelian et al. 1997) during the upwelling of cold and nutrient-rich waters (Piryaei et al. 2010), the fossil record and the absence of euphotic components suggest basinal conditions (Cosovic et al. 2004, van Buchem et al. 2010). These sediments are therefore interpreted as representing intra-shelf basin deposits (e.g. Piryaei et al. 2010, van Buchem et al. 2010).

\section{Open marine (B)}

\section{MF-type 4: Bioclastic pack- to rudstone (Fig. 13F)}

This microfacies is grain-supported and contains high amounts of skeletal debris. Bivalves, gastropods and echinoids $(\sim 35 \%)$ with sizes up to $4 \mathrm{~mm}$ are the most important components. In some case a relative large amount of corals (Fig. 10D) are observed. In more restricted parts, a lot of rudist shells are present (Fig. 13G). Brachiopods and scattered benthic foraminifers constitute the minor components. The shell beds formed by concentration of complete or broken shells (Fig. 9F) are characterized by mediumgrey limestone to argillaceous limestone with an upward trend in increasing of the proportion of fine particles. This is also observed in thin section. Serpulid tubes are attaching on different and variously sized bioclasts (Fig. 13H).

\section{MF-type 5: Orbitolinid pack- to rudstone}

\section{(Fig. 13I)}

This microfacies type is dominated by medium- to thickbedded, massive grey, partly argillaceous limestones. Flat tests of orbitolinids of 2-4 mm-size with large length/ height ratios are the main biotic components. Bivalves, echinoids, brachiopods and peloids are present at different concentration and in some parts only orbitolinids can be seen. Bioturbation, characterized by limonitic micrite, is pervasive in this facies, especially in the Kuh-e-Fahliyan and Kuzeh-Kuh sections.

\section{Interpretation}

Stenohaline fauna (bivalves, brachiopods, and echinoids) indicates normal marine conditions (Bachmann \& Hirsch 2006, Flügel 2010). The presence of discoidal orbitolinids is in agreement with interpretation (Pittet et al. 2002, Bachmann \& Hirsch 2006). The degree of shell fragmentation and the upward-fining trends in beddings suggests resedimentation of the different components (Rubert et al. 2012). This reflects relatively moderate water energy characteristic of wave-agitated platforms (Bover-Arnal et al. 2009, Laya \& Tucker 2012). The lack of evidences for turbidity currents suggests the deposition between the fair weather wave base and the storm wave base (Corda \& Brandano 2003, Bover-Arnal et al. 2009, Bassi \& Nebelsick 2010, Laya \& Tucker 2012). Such a high accumulation of shell fragments is interpreted as tempestite (Perez-Lopez \& Perez-Valera 2011, Chatalov 2013).

\section{Shoal (C)}

\section{MF-type 6: Peloidal grainstone (Fig. 14A)}

This grain-supported facies mainly consists of well-sorted, subspherical peloids (40-45\%, probably fecal pellets) with average diameters of $0.2-0.4 \mathrm{~mm}$. Small benthic foraminifers (miliolids), green algae, few intraclasts and, in the type section, ooids and conical orbitolinids are also present (in some parts up to $12 \%$ ).

\section{MF-type 7: Ooid grainstone (Fig. 14B)}

The main components ( $45-50 \%)$ of this grain-supported facies are radial and concentric ooids $(0.1-0.3 \mathrm{~mm})$. Their shapes vary from spherical to subelongate, mostly depending on the form of their nucleus. Composite ooids and aggregate grains of ooids are also observed. Peloids, benthic foraminifers and debris shells are common nuclei of ooids with that interval. The thickness of the cortex is related to the shape and the size of the nucleus with an inverse ratio. This facies is developed in the type section (Kuh-eGadvan). Cross-bedding and cross-laminations are the main sedimentary features observed in this facies. 

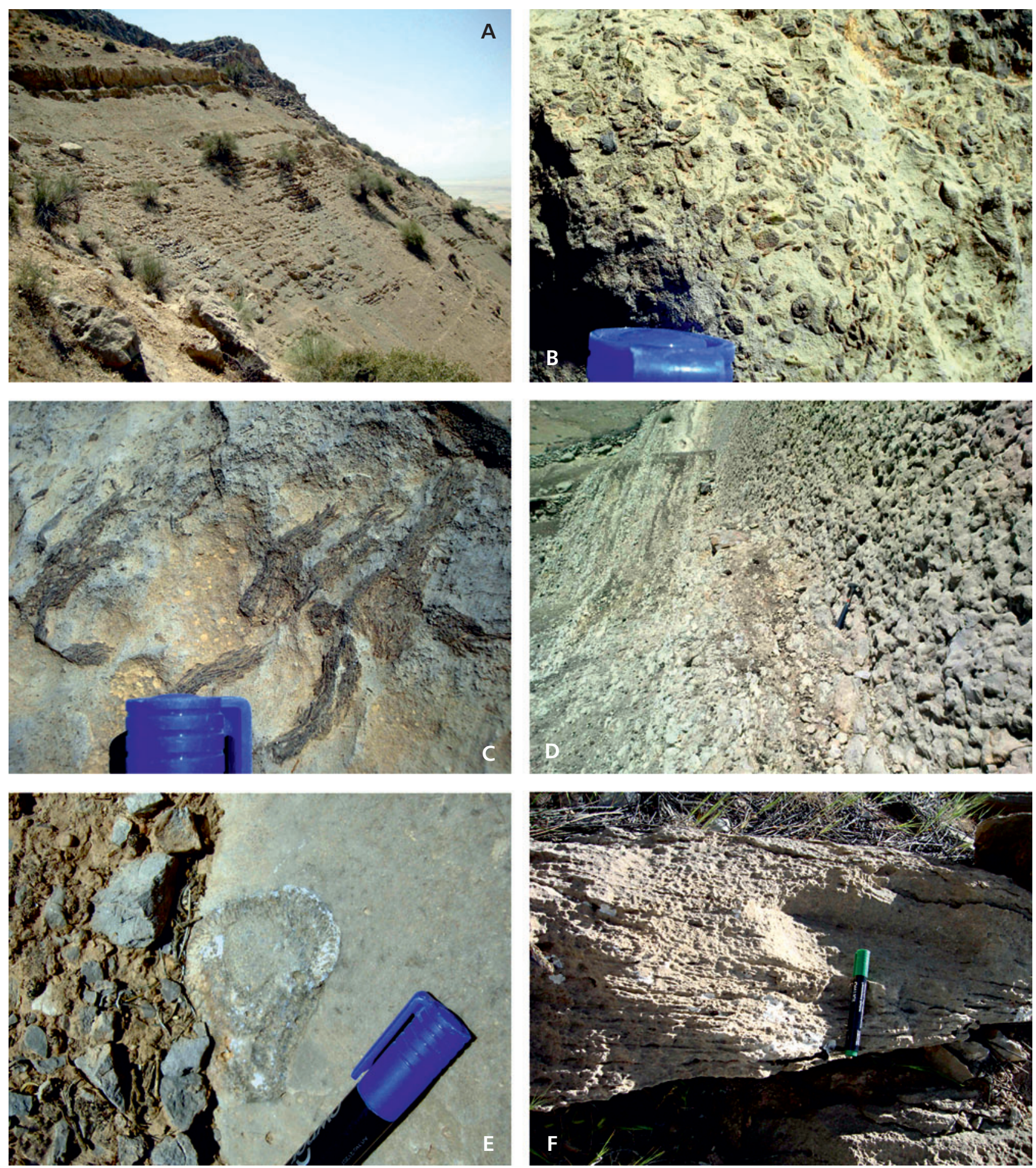

Figure 10. Field aspects of the Dariyan Formation. $\bullet$ A - alternation of shale, marl and argillaceous limestone in the Kazhdumi Tongue, at Kuh-e-Sefid. - B - orbitolinid dominated limestone, upper Dariyan, in the Kuh-e-Fahliyan section, $120 \mathrm{~m}$. $\bullet \mathrm{C}$ - corals at the massive carbonates of the type section, $260 \mathrm{~m}$. $\mathrm{D}$ - the Dariyan-Kazhdumi formational boundary with intense bioturbations at the Kuh-e-Fahliyan. $\bullet$ E - rudist shell at the Kuh-e-Gadvan, $75 \mathrm{~m}$. $\bullet \mathrm{F}$ - cross-lamination in cream-coloured limestone in the Khaneh-Kat section, $168 \mathrm{~m}$. 

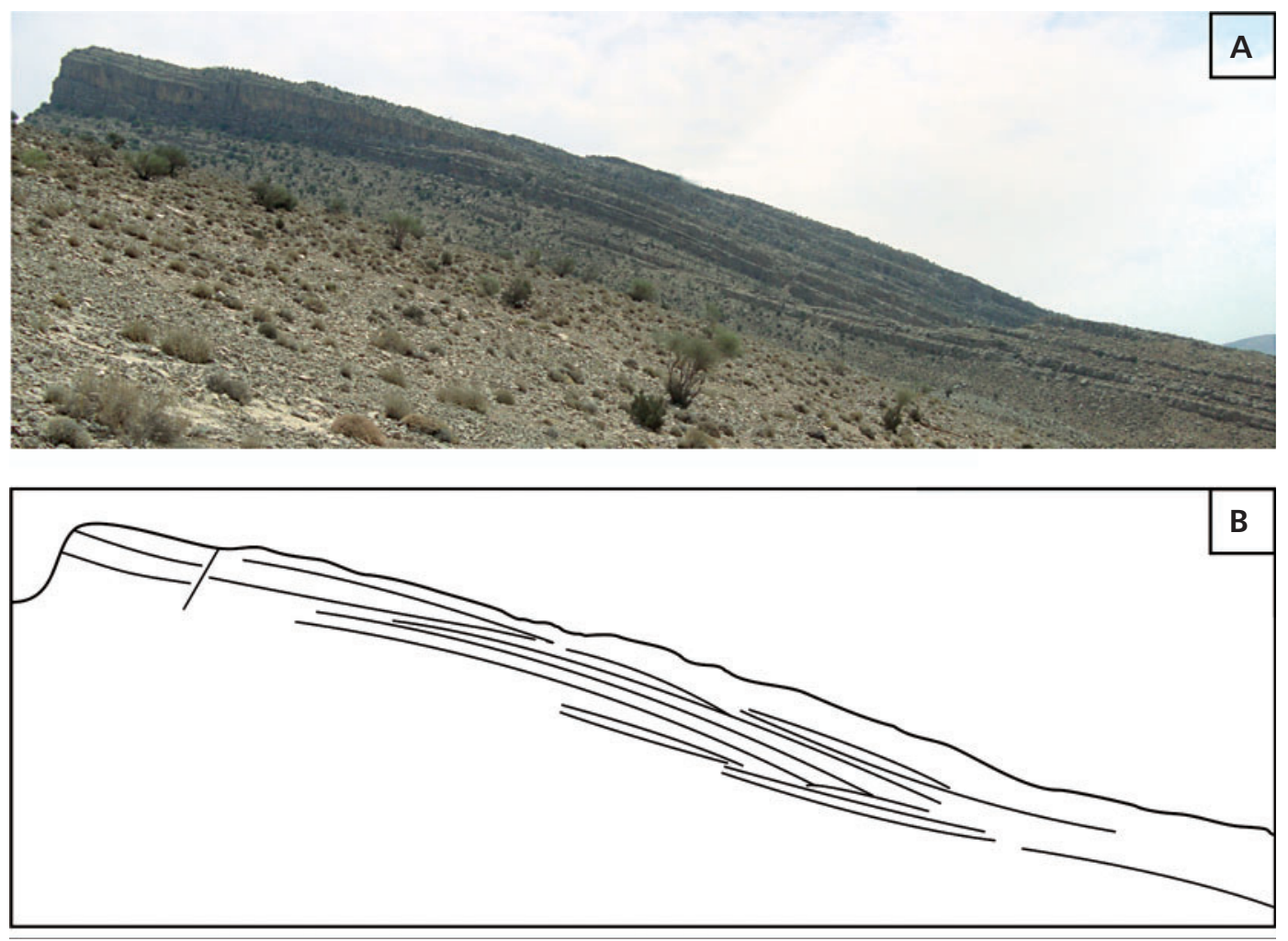

Figure 11. A - lateral thinning and sigmoidal beds (clinoform) in the upper Dariyan Formation in the Kuh-e-Sivand section. The inclination of progradation is from east to west. $\bullet \mathrm{B}$ - schematic drawing of the field photo. The approximately length of view is $600 \mathrm{~m}$.

\section{MF-type 8: Orbitolinid grainstone (Fig. 14D)}

Large discoidal orbitolinids are dominant components of this facies ( $35-40 \%$, size from $0.5-5 \mathrm{~mm}$ ) accompanied by peloids and intraclast. Small benthic foraminifers, conical orbitolinids, bivalve debris and concentric ooids are also present. Intraclasts are micritic, but aggregates of ooids and other lagoonal components are observed as well. In the type section, internal pores of orbitolinids have been filled by evaporitic minerals or quartz.

\section{MF-type 9: Bioclastic grain- to rudstone (Fig. 14D)}

This facies is characterized by brown limestone with cross-lamination and cross-bedding. Brachiopods, rudist, echinoids and bivalves with a size of $2-3 \mathrm{~mm}$ are the main components (40-45\%). Subordinate grains consist of orbitolinids, gastropods, crinoids, green algae and benthic foraminifers. Borings and micritic envelopes characterize many of the skeletal grains. In the type section, the abundance of green algae and benthic foraminifers (up to 20\%) is higher than in the other sections. Moreover, in the type section high accumulation of rudist shells formed patch reef. Non-skeletal grains are composed of peloids and intraclasts, which contain miliolids and green algae.

\section{Interpretation}

Well-washed and grain-supported texture with calcite cement, concentric ooid, cross-lamination and cross-bedding, rounded intraclasts and well-sorted grains indicate high energy environments (Masse et al. 2003, Palma et al. 2007, Bachmann \& Hirsch 2006, Armella et al. 2013). This is characteristic of setting situated above the fair weather wave base in a shoal environment (e.g. Bover-Arnal et al. 2009, Laya \& Tucker 2012).

\section{Lagoon (D)}

\section{MF-type 10: Peloidal green algae wackestone/packstone (Fig. 14E, F)}

This facies is defined by medium to massive, grey to dark-grey limestone beds, mainly composed of green algae ( 20\%). Salpingoporella dinarica and Lithocodium aggregatum are relatively abundant. Peloids, conical orbitolinids and miliolid foraminifers are less abundant (up to 15\%). Some samples of this interval are entirely composed of Salpingoporella dinarica (the sections of Kuh-e-Gadvan and Rahmat-Abad) or Lithocodium aggregatum (at KhanehKat). 

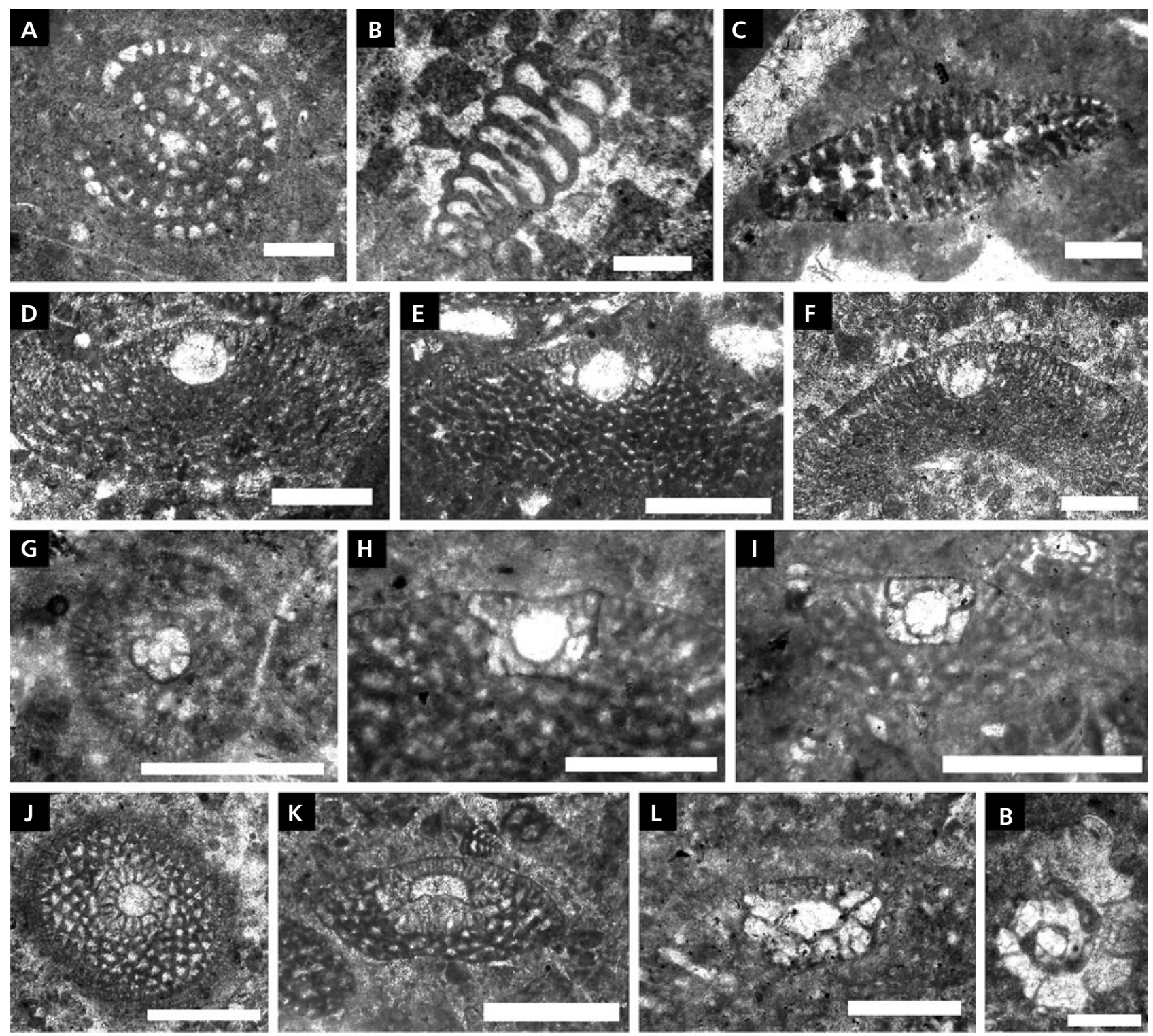

Figure 12. Benthic foraminifers of the Dariyan Formation and their position in the section. • A - Archaealveolina sp., axial section, at Rahmat-Abad, $65 \mathrm{~m}$, early Aptian. - B - Praechrysalidina infracretacea Luperto Sinni, axial section, in the type section (Kuh-e-Gadvan), $60 \mathrm{~m}$, early Aptian. - C - Choffatella decipiens Schlumberger, axial section, at Rahmat-Abad, 73 m, early Aptian. $\bullet$ D, E - Palorbitolina lenticularis (Blumenbach), primitive (D) and advanced (E) form, axial section, at Khaneh-Kat, $4 \mathrm{~m}$ and $34 \mathrm{~m}$ respectively, early Aptian. $\bullet \mathrm{F}-$ Palorbitolina aff. ultima Cherchi \& Schroeder, axial section, at Khaneh-Kat, $33 \mathrm{~m}$, early Aptian. $\bullet \mathrm{G}, \mathrm{H}-$ Mesorbitolina parva (Douglass), axial (G) and transversal (H) section, 112 and $138 \mathrm{~m}$ respectively, at Kuh-e-Fahliyan, late Aptian. - I, J - Mesorbitolina texana (Roemer), transversal (I) and axial (J) section, 135 and 168 respectively, at Kuzeh-Kuh, late Aptian. $\bullet \mathrm{K}-$ Mesorbitolina pervia (Douglass), axial section, in the type section, $230 \mathrm{~m}$, late Aptian. $\bullet \mathrm{L}-$ Mesorbitolina subconcava (Leymerie), axial section, at Kuh-e-Fahliyan, 192 m, late Aptian-early Albian. $・$ M - Hemicyclammina sigali Maync, equatorial section, in the Kuh-e-Fahliyan section, 228 m, early Albian.

\section{MF-type 11: Conical orbitolinid packstone/wackestone (Fig. 14G)}

The MF-type 11 is characterized by a relatively thick beds and massive grey limestone. The thin sections are dominated by conical orbitolinids $(40 \%)$ with a low length/height ratio and of variable size (ranging between 0.5 and $1.5 \mathrm{~mm}$ ). In some samples, benthic foraminifers and peloids have also been observed. Green algae, debris of bivalves and gastropods are subordinate. At Khaneh-Kat and Kuhe-Gadvan (the type section), this facies is represented by packstone/grainstone. 


\section{MF-type 12: Peloidal benthic foraminifer packstone/wackestone (Fig. 14H)}

Benthic foraminifers (miliolids, textularids and conical orbitolinids) and peloids are the most abundant components in this facies. The proportion of benthic foraminifers is 25-30\% and the proportion of peloids with uniform size (average $0.4 \mathrm{~mm}$ ) varies from 10 to $20 \%$. Green algae, sponge spicules and echinoid debris are present in lesser amounts.

\section{MF-type 13: Mudstone (Fig. 14I)}

This facies is defined by medium-to thick-bedded, grey to dark grey limestone to argillaceous limestone with horizontal lamination. The main character of this facies is homogenous lime mud matrix, which in some cases contains less than $10 \%$ skeletal grains, e.g. benthic foraminifers.

\section{Interpretation}

The dominated lime-mud texture is indicative of a low energy environment (Flügel 2010). The presence of skeletal grains of euryhaline biota such as green algae, miliolids and conical orbitolinids suggest restricted conditions with limited circulation (Mancinelli 2006, Afzal et al. 2011). Considering the observed vertical evolution within this interval, this association of facies has been interpreted as lagoonal deposits (e.g. Ghabeishavi et al. 2010).

\section{Depositional environment}

Based on the variations in textures and grain types, the facies evolution, and the sedimentary structures, the Dariyan Formation in the study area is interpreted as characterizing shallow homoclinal carbonate ramp to intra-shelf basin depositional settings (Read 1985; Burchette \& Wright 1992; Pomar 2001; Piryaei et al. 2010, 2011; van Buchem et al. 2010; Lu et al. 2013; Fig. 15). The distribution of the facies associations B, C, and D in the sections of Kuh-e-Gadvan, Rahmat-Abad and Khaneh-Kat and the gradual pattern of vertical and lateral transitions in microfacies and sub-environments (Read 1985, Burchette \& Wright 1992) suggest that these sediments have been deposited in shallow marine carbonate platform with low angle gradient, i.e. a homoclinal carbonate ramp (Afzal et al. 2011, Chatalov 2013). This is supported by the lack of barrier or rim (Read 1985, Pomar 2001, Ghabeishavi et al. 2010, Laya \& Tucker 2012), as well as by the absence of talus, turbidities sediments (Payros \& Pujalte 2008, Pomar et al. 2012) and restricted lagoonal facies (Read 1985, Ghabeishavi et al. 2010). The presence of the facies association A with a high content of offshore skeletal grains (globigerinelloids, hedbergellids, radiolaria) and macrofossils (ammonites) suggest that some part of the study area was characterized by deep marine to basinal sedimentation (Cosovic et al. 2004, Flügel 2010, Gorican et al. 2012). Considering the location and limited distribution of this microfacies association, the most likely depositional setting is an intra-shelf basin surrounded by shallow platform sediments (Sharland et al. 2001, Ziegler 2001, van Buchem et al. 2010, Pomar et al. 2012).

Given the different microfacies type distribution, especially the position of the fair weather wave base (FWWB) and the storm wave base, three facies belt can be distinguished: inner ramp (lagoon and shoal), middle ramp (open marine) and outer ramp (intra-shelf basin) (Burchette \& Wright 1992; Fig. 15). The inner ramp biotas, such as miliolid foraminifera and conical orbitolinids, dasycladacean green algae or bacinellid microbial crusts, suggest that the uppermost part of the Dariyan Formation was deposited within the photic zone (Romero et al. 2002, Ghabeishavi et al. 2010). Furthermore, texture and sedimentary structures of shoal facies reflect deposition above FWWB (Bover-Arnal et al. 2009, Bassi \& Nebelsick 2010, Chatalov 2013). In the middle ramp, large benthic foraminifers such as discoidal orbitolinids (dependant on photosynthetic symbionts) suggest euphotic condition in the zone situated between the FWWB and the SWB (Romero et al. 2002, Corda \& Brandano 2003, Bassi 2005, Bover-Arnal et al. 2009). Finally, the outer ramp belt is characterized by the presence of planktonic foraminifers and the absence of phototrophic organisms (Cosovic et al. 2004, Gorican et al. 2012). This indicates the deposition below the photic zone and storm wave base (Corda \& Brandano 2003, Penney \& Racey 2004, Payros et al. 2010, van Buchem et al. 2010).

\section{Sequence stratigraphy}

As the lateral facies change are mainly reflecting lateral variations in depositional conditions, the observed vertical trends seem to be controlled by changes in eustatic sea-level, tectonic subsidence and sediment supply (Galloway 1989, Schlager 2005). Indeed, sea-level fluctuations are known to produce variation in sedimentary deposition, forming cycles of sequences showing change in accommodation or sediment supply (Catuneanu et al. 2009). Based on the sequence stratigraphic analysis (van Wagoner et al. 1988, 1990; Vail et al. 1991; Cantalamessa et al. 2006; Bover-Arnal et al. 2009; Catuneanu et al. 2009; Spengler \& Read 2010), three $2^{\text {nd }}$-order depositional sequences (DS-1, DS-2 \& DS-3) separated by type 2 sequence boundary have been recognized in the Dariyan Formation (Figs 16, 17). The basal boundary of the Dariyan Forma- 

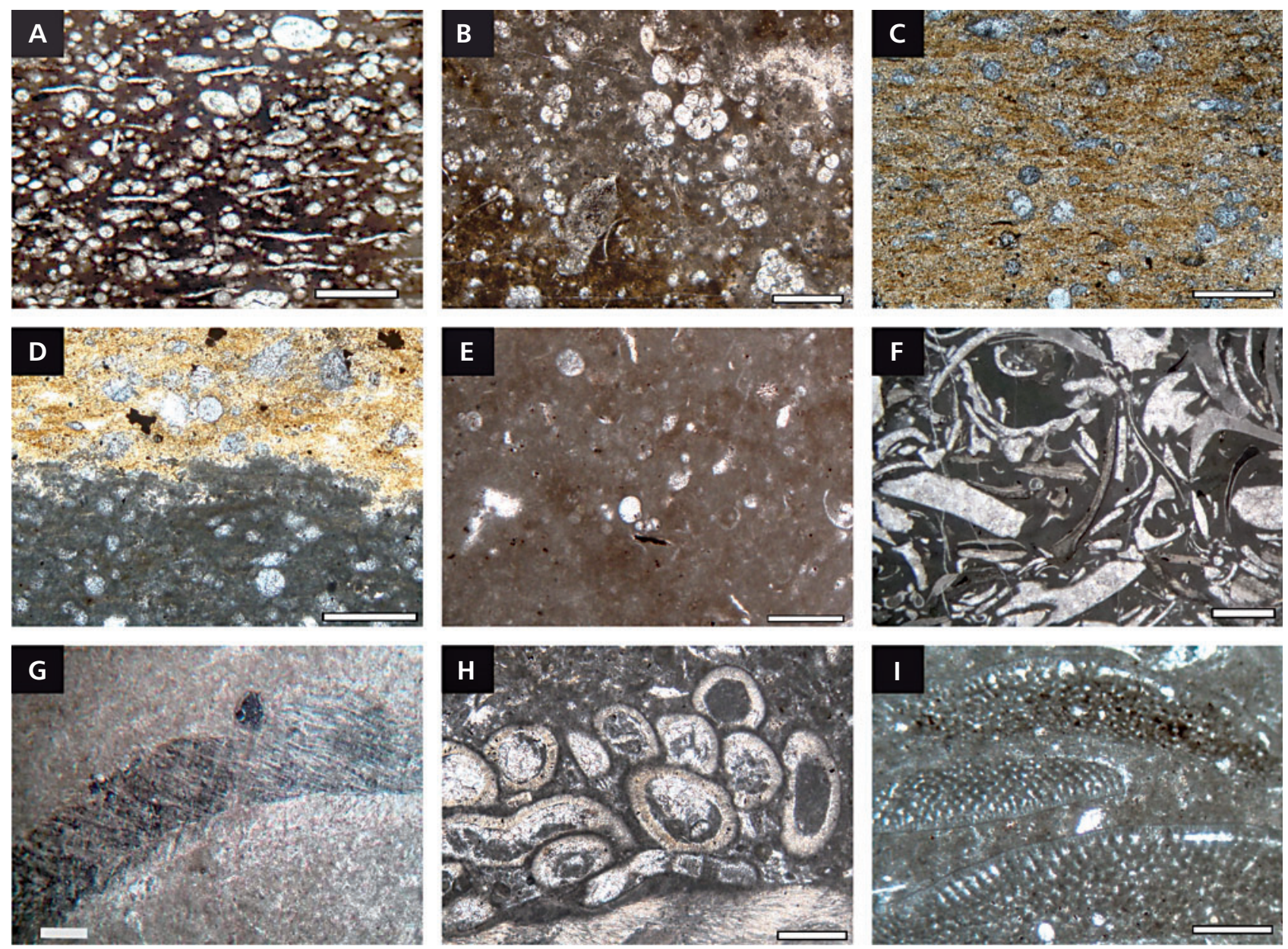

Figure 13. Outer and mid ramp microfacies types of the Dariyan Formation. $\bullet A-M F 1$ : radiolarian packstone with lime-mud matrix which contains organic matter (basin) (in the Kuh-e-Sefid section, $44 \mathrm{~m}$ ). B - MF2: planktonic foraminifer packstone with organic matter in matrix (basin) (at Kuzeh-Kuh, $38 \mathrm{~m}$ ). $\bullet \mathrm{C}$ - chert with different amounts of radiolarians (in the Kuh-e-Fahliyan section, $34 \mathrm{~m}$ ). $\bullet \mathrm{D}$ - the same fauna with different matrix, pelagic limestone-chert interbed boundary (in the Kuh-e-Fahliyan section, $33 \mathrm{~m}$ ). $\bullet \mathrm{E}-\mathrm{MF} 3$ : planktonic foraminifer wackestone (deep open marine) (at Kuzeh-Kuh, $29 \mathrm{~m}$ ). $• \mathrm{~F}$ - MF4: poorly sorted bioclastic micritic rudstone, thin section shows poor roundness of components (open marine) (in the Rahmat-Abad section, $93 \mathrm{~m}$ ). $\bullet \mathrm{G}$ - rudist shell in packstone facies (top platform) (at Kuh-e-Gadvan, $108 \mathrm{~m}$ ). $\bullet \mathrm{H}-$ serpulid tubes fixed to a rudist shell. These tubes observed in uniform size in mudstone microfacies (wide range of environments) (in the Kuzeh-Kuh section, $134 \mathrm{~m}$ ). $\bullet \mathrm{I}-$ MF5: orbitolinid packstone with discoidal forms (open marine) (Kuh-e-Sefid, $158 \mathrm{~m}$ ).

tion is an isochronous surface observed in all parts of platform whereas the top boundary seems to be diachronous. This is shown by evidences of exposure in the shallow parts of platform (i.e. Coastal Fars; Schroeder et al. 2010, van Buchem et al. 2010). The three $2^{\text {nd }}-$ order depositional sequences can be divided into six and five $3^{\text {rd }}$-order sequences in basinal and platform parts of basin, respectively (Figs 16, 17). In this study, the top boundary of Gadvan Formation has been regarded as a datum for the sequence stratigraphy analysis.

The upper part of the Gadvan Formation was deposited during a regressive phase when the siliciclastic material settled over the flat platform in the Late Barremian (Davies et al. 2002). These sediments are regarded as belonging to a late highstand system tract (Davies et al. 2002, van Buchem et al. 2010). A subsequent sea-level rise and the related facies transgression observed are reflected by the deposition of the Dariyan carbonate platform over these marly intervals (Sharland et al. 2001, Davies et al. 2002, van Buchem et al. 2010). Since the top sequence boundary of the Barremian sequence is placed within the upper marly interval of Gadvan Formation and cannot be positioned distinctively, the formational boundary between the Gadvan and Dariyan formations is considered at the base of SB-D-1 for Aptian sediments (Dariyan Formation) (Figs 16 and 17). According to the definition of a sequence boundary, the SB-D-1 can be recognized by a sudden change in lithology and facies characterized by an abrupt transition from argillaceous marl to bivalve-dominated facies in basin part. This boundary is also characterized by transition from alternation of marl and argillaceous limestone to algal and benthic foraminifer-bearing carbonate 
facies in platform part. This SB-D-1 surface has been observed in other part of the ZFTB and can be correlated over most parts of this area (James \& Wynd 1965, Motiei 1993, van Buchem et al. 2010).

The first sequence is characterized by medium- to thin-bedded grey argillaceous limestone with an upwardthinning trend in the intra-shelf basin part and relatively medium to thick-bedded limestones in platform part (Figs 16, 17). The thickness of this succession varies between $63 \mathrm{~m}$ for the platform settings to $26 \mathrm{~m}$ for the intra-shelf basin settings. Narrow lateral variation in facies could be distinguished from Khaneh-Kat to Kuh-eFahliyan sections characterized by restricted green algaeand benthic foraminifer-dominated carbonate to more open marine limestone contains oyster, gastropod and bivalve in this phase. In the intra-shelf basin part, the transgression led to shell beds accumulations, formed by bioclast packstone with high accumulations of bivalve shells. The top surface of this interval is regarded as a flooding surface (FS - Figs 16, 17; e.g., Gharsalli et al. 2013). In the platform part, the transgressive sequence led to the depositions of bioclast grainstone with relatively discoidal orbitolina and rudist debris at Kuh-e-Gadvan and Khaneh-Kat. In Rahmat-Abad, this is characterized by discoidal orbitolinids dominated packstone with shallow open marine features. The top of bed showing the deepest facies (FZ) is considered as representing the flooding surface (FS; e.g., Saber 2012). This succession is interpreted as an early transgression phase, and probably corresponds to the Apt1 phase on Arabian Plate (e.g. van Buchem et al. 2010).

The second phase of transgression is well expressed, in the intra-shelf basin part of the studied area, by a rapid change from open marine to pelagic facies accompanied by a thinning-upward trend and more fine-grained deposition. Thin-bedded (up to $40 \mathrm{~cm}$ ) black limestone to argillaceous limestone with mm-lamination, nodular and thin bedded (up to $15 \mathrm{~cm}$ ) black cherts and ammonites, which are overlain by grey marls, are main features of this sequence in this part. The radiolarians and planktonic foraminifers are main components of wackestone and packstone facies in this interval - "Radiolarian Flood Zone" (RFZ; e.g. van Buchem et al. 2010). This interval is seen as the Maximum Flooding Zone (MFZ; van Buchem et al. 2010, Piryaei et al. 2011). The top surface of this interval shows evidences for low sedimentation rates, e.g. ammonite fauna (Vincent et al. 2010) and iron crust (e.g. van Buchem et al. 2010; Fig. 9H), thus representing the maximum flooding surface (MFS) in intra-shelf basin setting (Figs 16, 17). In the shallower sections (platform part), the MFZ is characterized by medium-bedded limestone to argillaceous limestone with wackestone and packstone containing open marine fauna (echinoid, bivalve and discoidal orbitolina) (e.g., Saber 2012). In the sections of Rahmat-Abad and Kuh-e-Gadvan, few sponge spicules were found at the top of this interval.
The stratigraphic position of the MFS in the platform part is located at the top surface of MFZ and is coeval with the first occurrence of Palorbitolina ultima (Schroeder et al. 2010). The thickness of this interval is relatively variable, ranging from $9 \mathrm{~m}$ at Kuh-e-Fahliyan (intra-shelf basin) to $48 \mathrm{~m}$ at Rahmat-Abad (platform). This is interpreted as a late transgression phase, corresponding to the Apt2 depositional sequence on Arabian Plate (van Buchem et al. 2010). The stacking patterns and thickness variations of these two successions (Apt1 and 2) show aggradation features in platform part (van Buchem et al. 2010).

The third phase of sea-level fluctuations is documented in intra-shelf basin sections (Kuh-e-Fahliyan, Kuzeh-Kuh and Kuh-e-Sefid) with the deposition of relatively homogenous marly interval with thin interbeds of argillaceous limestone containing pelagic fauna of planktonic foraminifers. At the top-platform sections (especially at KhanehKat and the type section) the medium-bedded carbonates with semi restricted shallow marine packstone and grainstone facies containing bivalve, rudist and benthic foraminifers are extended. This interval characterized by the assemblage A has been dated as late early Aptian. The changes in facies and sedimentary condition from open marine to more restrict conditions show a gradual shallowing trend, interpreted as a highstand phase. This corresponds to the Apt3 depositional sequence (e.g. van Buchem et al. 2010, Saber 2012). The top surface of this interval (dated as latest early Aptian based on the orbitolinids) is almost coeval with the first occurrence of Mesorbitolina parva in the study area (Schroeder et al. 2010, van Buchem et al. 2010). This highstand is mostly covered on margin of intra-shelf basin and leads to the top sequence boundary of DS-1 in this area. The top of this interval (SB-D-2) recorded an abrupt facies change in three basinal sections where orbitolinids-dominated wackestone/packstone is overlying intra-shelf basin marls with planktonic foraminifer fauna. The SB-D-2 is the basal sequence boundary for upper Aptian supersequence in the study area (e.g. van Buchem et al. 2010).

DS-2 in the study area corresponds to the Kazhdumi Tongue and upper Dariyan interval in margin of intra-shelf basin settings (Figs 16, 17). The base of the sequence boundary (SB-D-2) is described above. The position of this transgressive systems tract $(\mathrm{Apt} 4)$ in the study area has been determined based on the presence of Mesorbitolina parva in the deposits of the assemblage B (Schroeder et al. 2010, van Buchem et al. 2010). The corresponding platform deposits are characterized by wackestone/packstone (and locally grainstone) facies containing open marine fauna (rudist, bivalve, gastropod and benthic foraminifers). The top surface of this interval regarded as MFS in this setting and the corresponding marginal basin facies is placed in the uppermost part of the Kazhdumi Tongue. In the 

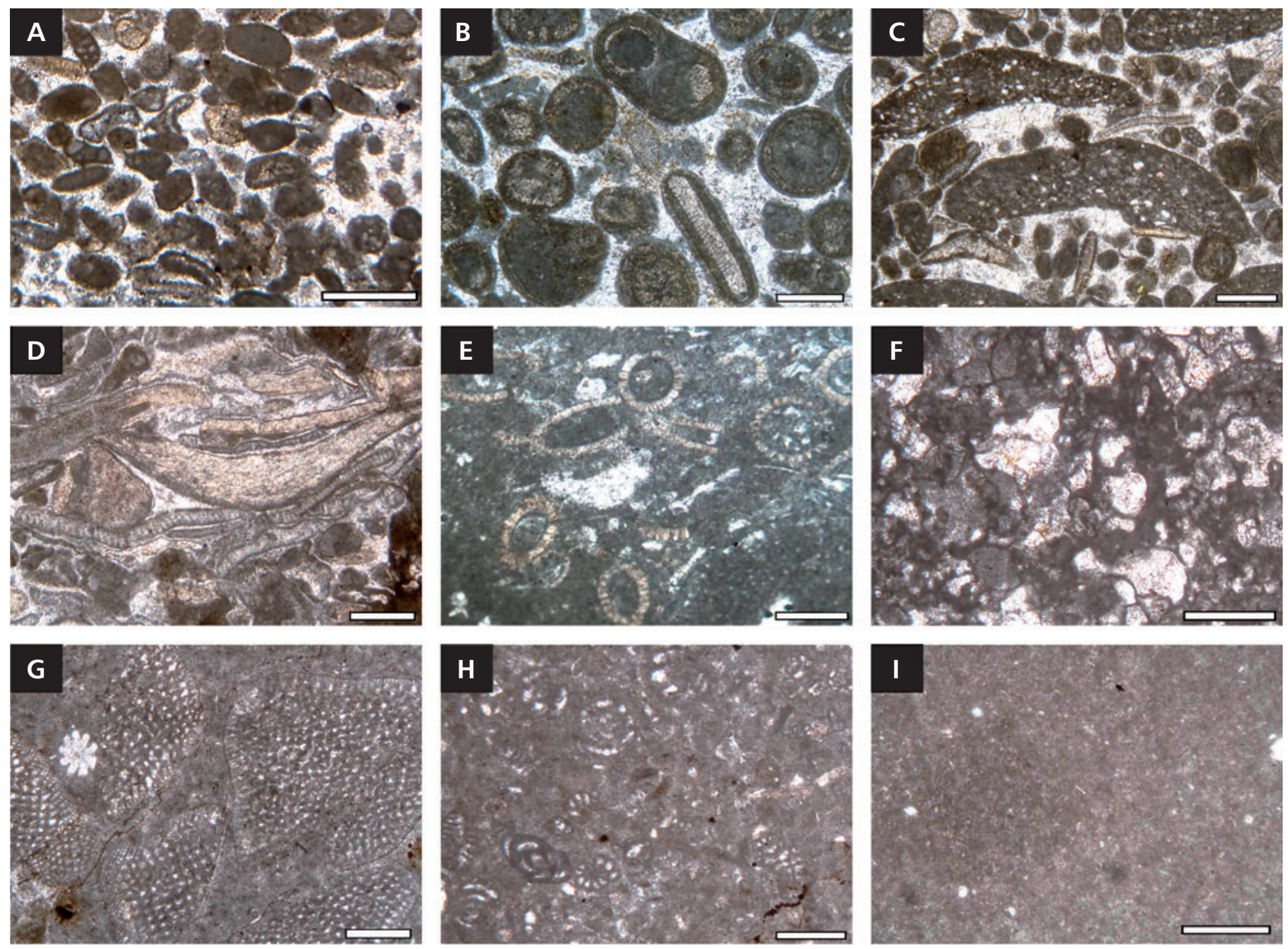

Figure 14. Inner ramp microfacies types of the Dariyan Formation. A - MF6: well-sorted peloidal grainstone, small benthic foraminifers are subordinate (landward shoal) (at Khaneh-Kat, $150 \mathrm{~m}$ ). B - MF7: ooid grainstone facies in medium- to thin-bedded limestone, the cores are peloids and bioclast fragments (landward shoal) (type section, $136 \mathrm{~m}$ ). $\bullet \mathrm{C}-\mathrm{MF}$ : discoidal orbitolinid grainstone (rudstone), ooids and small benthic foraminifers are subordinate (basinward shoal) (type section, $153 \mathrm{~m}$ ). $\bullet$ D - MF9: high-diversity bioclastic rudstone with intraclasts and peloids. Micritic envelopes can be observed (basinward shoal) (in the Khaneh-Kat section, 189 m). E - MF10: peloidal wackestone/packstone with thalli of Salpingoporella dinarica Radoicic and F - "bacinellid" microbial crust (lagoon) (at Rahmat-Abad, 170 and $175 \mathrm{~m}$ ). $\bullet \mathrm{G}-\mathrm{MF} 11$ : packstone with conical orbitolinids (lagoon) (at Kuh-e-Sefid, $162 \mathrm{~m}$ ). $\bullet \mathrm{H}-\mathrm{MF} 12$ : peloidal wacke-/packstone with milliolid benthic foraminifera such as Archaeoalveolina sp. (landward lagoon) (in the Khaneh-Kat section, 253 m). $・$ I - MF13: mudstone (landward lagoon) (at Rahmat-Abad, 83 m).

Apt 3 and 4, rudist shells are generally more abundant in the shallow platform sections, but in lesser amounts as it has been observed in coeval deposits from the southern part of the Arabian Plate (UAE: Wilson 1975, Yose et al. 2006; Oman: Witt \& Gokdog 1994, van Buchem et al. 2002; Qatar: Raven et al. 2010). According to the trends of facies evolution described above, this interval is interpreted as corresponding to transgressive system tract. In the margin of intra-shelf basin, Apt 4 is determined by its distinctive basal and top boundaries.

The highstand sediments of DS-2 characterized by thick to massive shallow carbonate deposits contain green algae and benthic foraminifers (miliolids and conical orbitolinids) in the platform part and orbitolinid-rich thick-bedded wackestone and packstone on the margin of intra-shelf basin setting. Such a trend in facies variations correspond to a highstand system tract (HST), and has been correlated to Apt5 on Arabian Plate based on the presence of Mesorbitolina parva and Mesorbitolina texana in the deposits of assemblage B (Schroeder et al. 2010, van Buchem et al. 2010). The thickness variations show a lateral variability with a thickening trend from the platform (85 $\mathrm{m}$ at Khaneh-Kat) towards the intra-shelf basin (168 m at Kuh-e-Sefid), and a thinning trend from margin of the intra-shelf basin (at Kuh-e-Sefid) towards the more central part (100 $\mathrm{m}$ at Kuh-e-Fahliyan). The Apt5 lead to top boundary of the Dariyan Formation in three platform sections and to the Apt6 on margin of intra-shelf basin setting (Figs 16,17). This surface is regarded as sequence boundary (SB-D-3) capping the DS-2 in the study area. According to the regional sequence stratigraphy of the Arabian Plate, this interval (Apt5) is interpreted as a progradation 


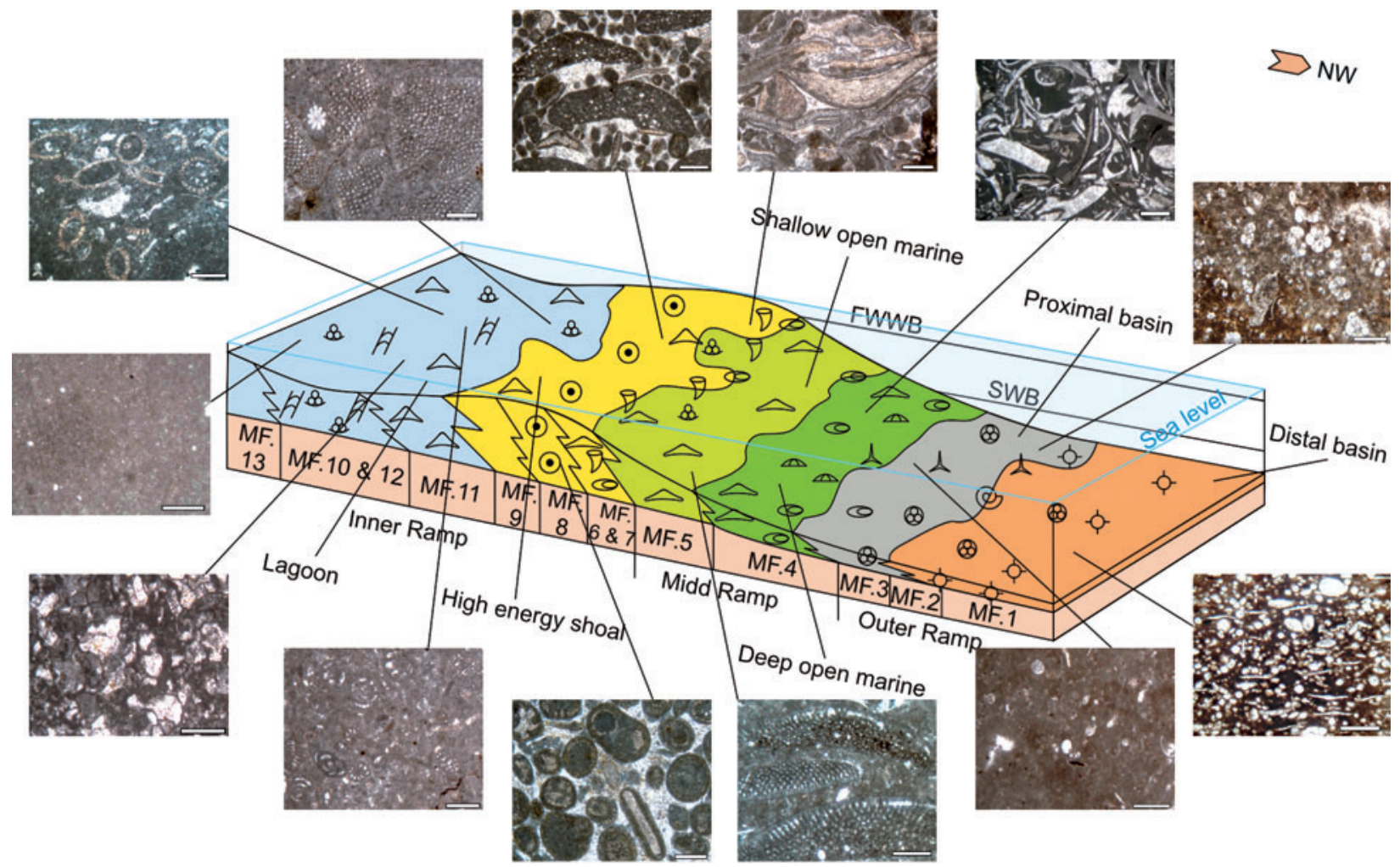

Figure 15. Schematic model for carbonate platform environments of the Dariyan Formation in the study area based on interpretation of facies belts, sedimentary environments and their lateral relationships. Distribution of facies and their codes showed on the model. Abbreviations: FWWB - fair-weather wave base; SWB - storm wave base (see Fig. 4 for the legend).

of shallow water carbonates to deeper parts of the basin and indicates lowstand systems tract (LST; e.g. van Buchem et al. 2010).

The last systems tract of the Dariyan Formation is only recorded in the basin sections (i.e. the sections of Kuh-eFahliyan, Kuzeh-Kuh and Kuh-e-Sefid) and is characterized by the assemblage $C$ (Figs 16, 17). This has been dated as uppermost Aptian-lower Albian deposits based on the presence of Mesorbitolina subconcava and Hemicyclammina sigali (Schroeder et al. 2010, van Buchem et al. 2010). This interval is characterized by a deepening trend in facies evolution and a thinning trend in stacking pattern. This is interpreted as an early transgression phase in DS-3 (Apt6; e.g. van Buchem et al. 2010). The basal sequence boundary was defined above (SB-D-3) while the top sequence boundary coincides with the top boundary of the Dariyan Formation. This surface reveals pervasive bioturbation evidenced in the Kuh-e-Fahliyan section and is considered as the FS of Apt6 (e.g. van Buchem et al. 2010, Khalifa et al. 2013). The weathered marl and shale of the Kazhdumi Formation overlies this boundary conformably. A conceptual sequence-stratigraphic model shows the distribution and relationships between facies and depositional sequences in different parts of the basin (Fig. 18).

\section{Discussion}

The first phase of sea-level rise at the Barremian-Aptian boundary displaced the depositional environments landwards to the west (Davies et al. 2002, van Buchem et al. 2010). As a result, the lowermost sediments (Apt1) of the Dariyan Formation were deposited in the eastern parts of the Arabian Plate (early TST; Sharland 2001, Davies et al. 2002, van Buchem et al. 2010). Time equivalent lateral changes of facies in the Dariyan Formation sediments, from the Interior Fars Province to the Izeh Zone, are interpreted as a subtle subsidence during the initial phase of intra-shelf basin evolution (van Buchem et al. 2010). No detailed biostratigraphic data are available to correlate the FS of Apt 1 with other parts of the Arabian Plate. However according to the early Aptian sequence stratigraphy model of the Arabian Plate during early Aptian the FS can be correlated with K70 (Sharland et al. 2001, Zigler 2001, van Buchem et al. 2010). In Kuwait and south Iraq, K70 has been recorded in the basal limestone of the Shuaiba Formation and can be correlated with the terminal deposits of the Zubair Formation and other deltaic siliciclastic sediments in central Arabia (Al-Fares et al. 1998). In the UAE, the uppermost calcareous shale of the Kharaib Formation (Hawar Member) is an equivalent the K70 (Azzam \& 


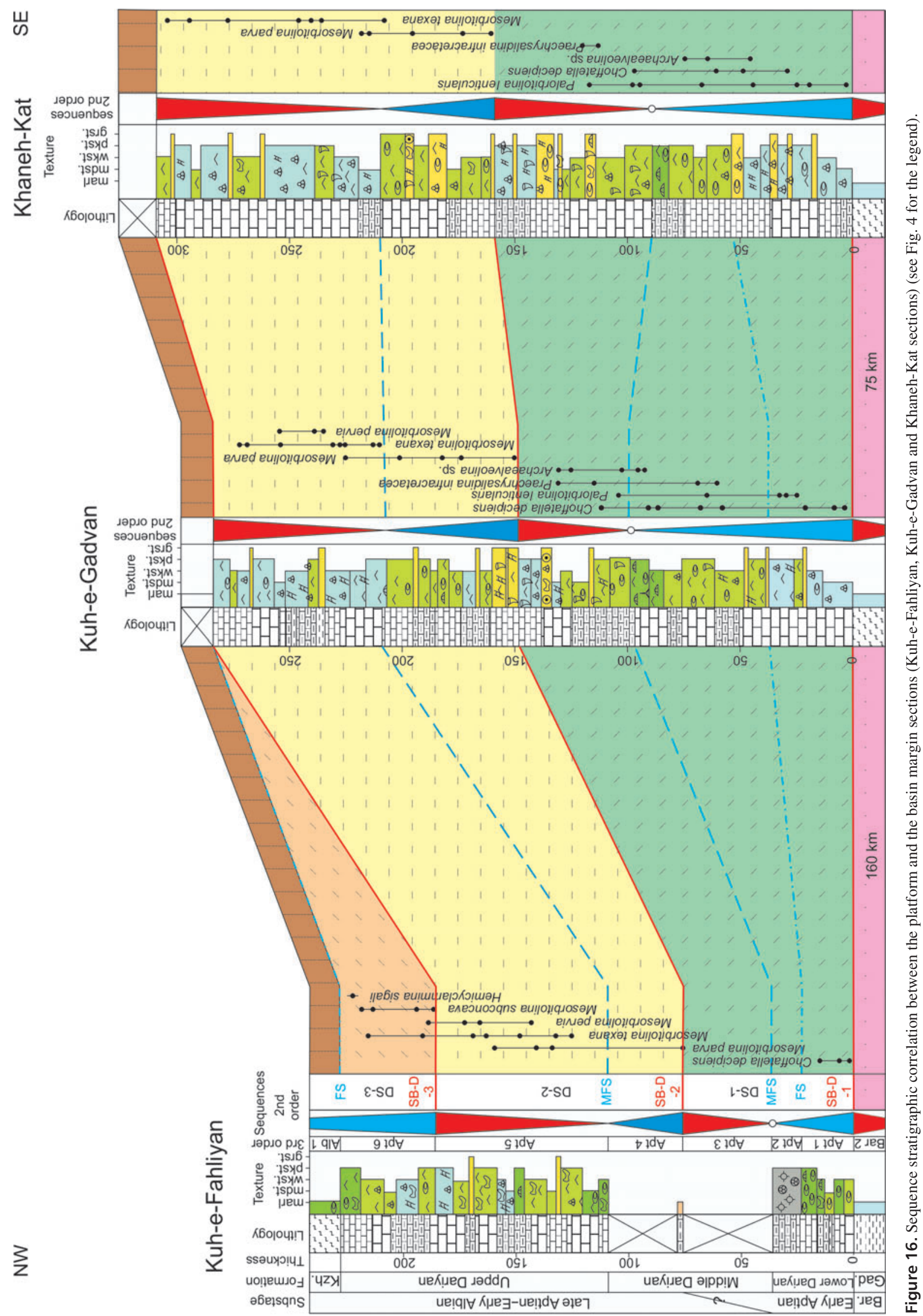


Taher 1995, Grotsch et al. 1998). The Hawar Member have led to the changes in sedimentary conditions dominated by fluvial systems (Biyadh Formation) to a marine carbonates-dominated sedimentary system (Shaiba Formation) in Saudi Arabia (Hughes 2000). Eustasy has been proposed as the driving mechanism controlling the first early Aptian transgression on the Arabian Plate (Sharland et al. 2001). Matthews \& Frohlich (2002) suggested that ice meltig due to orbital forcing is the main controlling factor for earliest Aptian transsgression (K70).

In Apt2, the shallowing/deepening trend suggests a second phase of sea-level rise on Arabian Plate during late early Aptian (van Buchem et al. 2010), probably controlled by eustatic variations (Sharland et al. 2001, Ziegler 2001). As previously mentioned, the uppermost part of lower Dariyan contains pelagic limestone with pelagic fauna (planktonic foraminifers, radiolarians and ammonites) associated with thin-bedded black chert and shale and higher contents of organic matter (Figs 9A-C, 19B). According to the carbon isotope stratigraphy of the Kuh-e-Sefid section, Moosavizadeh et al. (2013) recently showed that these features reflect the expression of the early Aptian oceanic anoxic event, so called OAE1a. OAE1a has been triggered by an increase of volcanic activity leading to higher $p \mathrm{CO}_{2}$ into the atmosphere. This led to intensified greenhouse conditions (Weissert \& Erba 2004, Mehay et al. 2009). This resulting global warming may have led to the melting of ice sheets (Frakes et al. 2005) and thus, the drowning of carbonate platforms due to sea-level rising in the Tethyan realm (Skelton \& Gili 2012).

The maximum flooding surface of the Apt 2 coincides with K80 MFS on Arabian Plate (Sharland et al. 2001, Zigler 2001, van Buchem et al. 2010). This MFS is well known from the Bab Tar (source rock) unit of the Shuaiba Formation in the United Arab Emirates as a basinal, planktonic foraminifer and organic-rich facies (Bab Basin; Grotsch et al. 1998). These characteristics are similar to the features of the Apt 2 at the Kuh-e-Sefid. This MFS has also been identified in the Shuaiba Formation (Qatar; Sharland et al. 2001) and in western Oman (Witt \& Gokdog 1994).

For K80, it has been shown that eustasy and tectonic subsidence of some parts of the Arabian Plate enhanced the rate of transgression and led to the evolution of intra-shelf basins (Sharland et al. 2001, Ziegler 2001, van Buchem et al. 2010). In the study area, the rapid transgression in intra-shelf basin setting compared to the coeval gradual facies variations (aggradational stacking patterns on platform parts) may reflect differential sedimentation processes. This is interpreted as the main phase of intra-shelf basin evolution, which results in increase in the subsidence rates (e.g. van Buchem et al. 2010; Piryaei et al. 2010, 2011). The same differentiation in stacking patterns and in transgression rates is observed between the Bab Basin sedi- ments and Shuaiba ramp platform deposits (Calavan et al. 1992).

The activation of the Kazerun and Hendijan faults has been considered as the main controlling factor on subsidence and the development of an intra-shelf basin in study area (Sepehr \& Cosgrove 2004, van Buchem et al. 2010). Nevertheless, the presence of intra-shelf basin facies $100-150 \mathrm{~km}$ away from the Kazerun Fault, i.e. at Kuh-e-Sefid (this study) and at Kuh-e-Sivand (Safari 2007) suggests that the intra-shelf basin extension is not limited to this fault and other factors may have played a role in the basin evolution. Coeval normal fault systems with extensional brittle activities were active in the Interior Fars Province (Navabpour et al. 2010). Additionally, synsedimentary movements of infra-Cambrian Hormuz Salt has been reported and have influenced the evolution of the intra-shelf Bab Basin on the Arabian Plate during the early Aptian (Sharland et al. 2001, Al-Gamdi 2006). As stated above, thickness variation in sequences from the Interior Fars Province to the Izeh Zone (especially in early Aptian) is an indicator of differential sedimentation that could have governed, at least partially, the development of intra-shelf basin (Calavan et al. 1992, van Buchem et al. 2002, Piryaei et al. 2011).

During the highstand phase, Apt 3 is considered to represent the HST of the DS- 1 sequence. The presence of marly interval (Kazhdumi Tongue) on margin of intrashelf basin settings and grain-dominated facies associated with a shallowing trend in the platform settings suggest an ongoing subsidence of the intra-shelf basin during this period of time. In the southeast parts of Arabian Plate (Oman, Qatar and southwest Iran), Apt 3 is characterized by an extensive subaerial exposure leading to the non-deposition of Apt4 sediments (van Buchem et al. 2010). The succession of the sedimentary packages (see facies description) indicates that the SB-D-2 is located at the top of the Apt3 interval (latest early Aptian) in the study area. In the Interior Fars Province and Izeh Zone, the sedimentary record, especially the presence of the assemblage B suggests the absence of sedimentary gaps and an uninterrupted record of the early late Aptian.

The sedimentary interval of Apt 4 characterized by Mesorbitolina parva bearing carbonate is documented in all the studied sections. This phase of sea-level rise occurred at the early late Aptian (assemblage B) and as a result, the uppermost sediments (Apt4) of the Kazhdumi Tongue and its time equivalent open marine facies of the Dariyan Formation sediments were deposited in the margin of intra-shelf basin and top-platform setting, respectively. The sea level rise is locally and probably controlled by combination of local tectonically subsidence and eustatic variations. The early late Aptian transgressive systems tract (Apt4) is not recorded over most parts of the Arabian Plate as a result of subaerially exposure of the area during 
兆

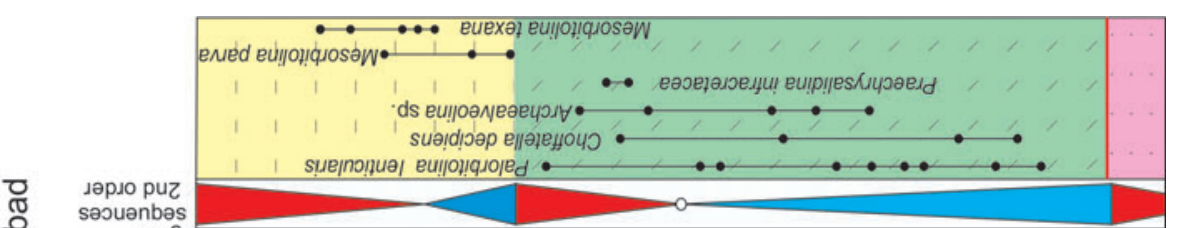

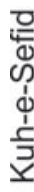

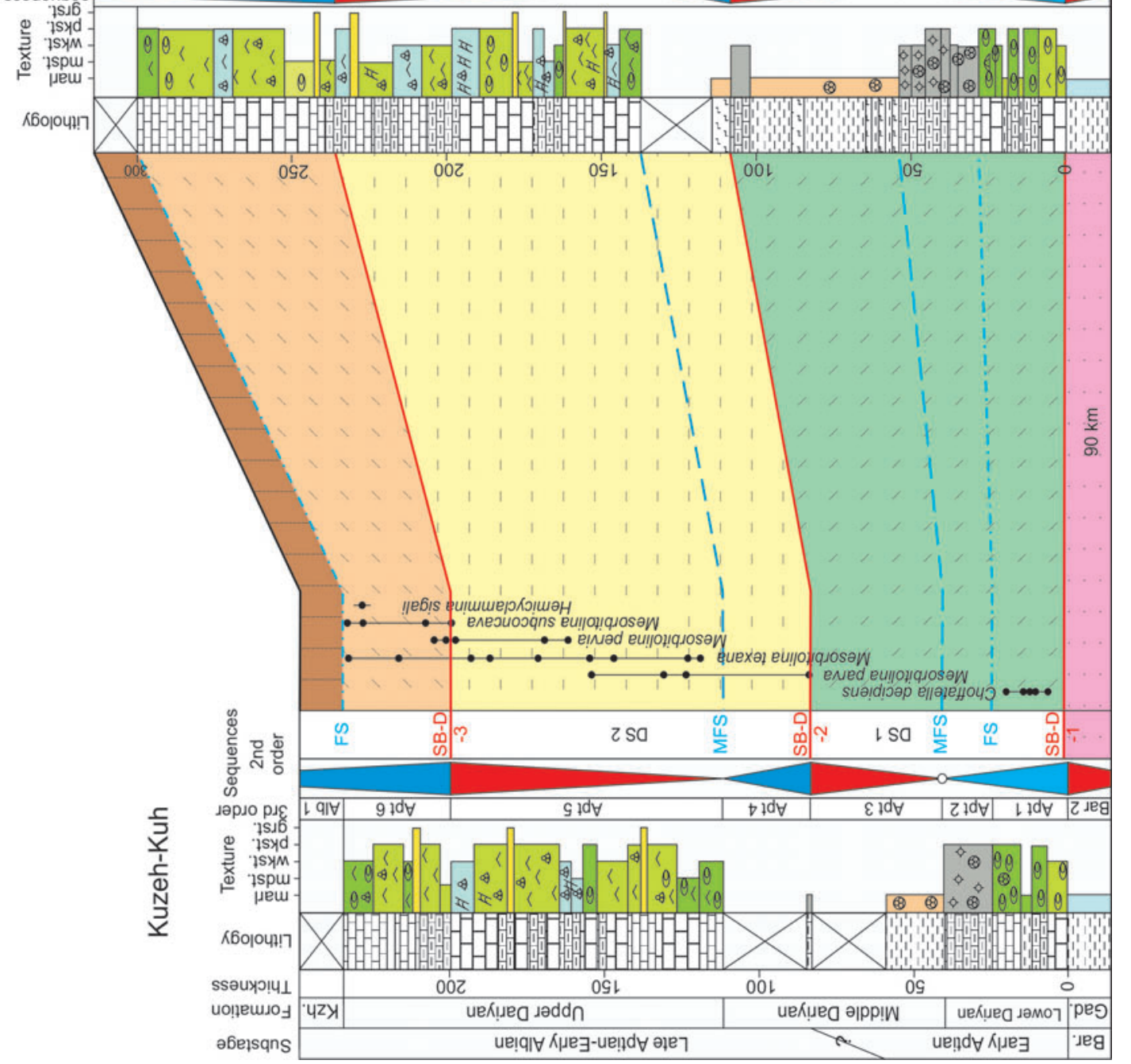




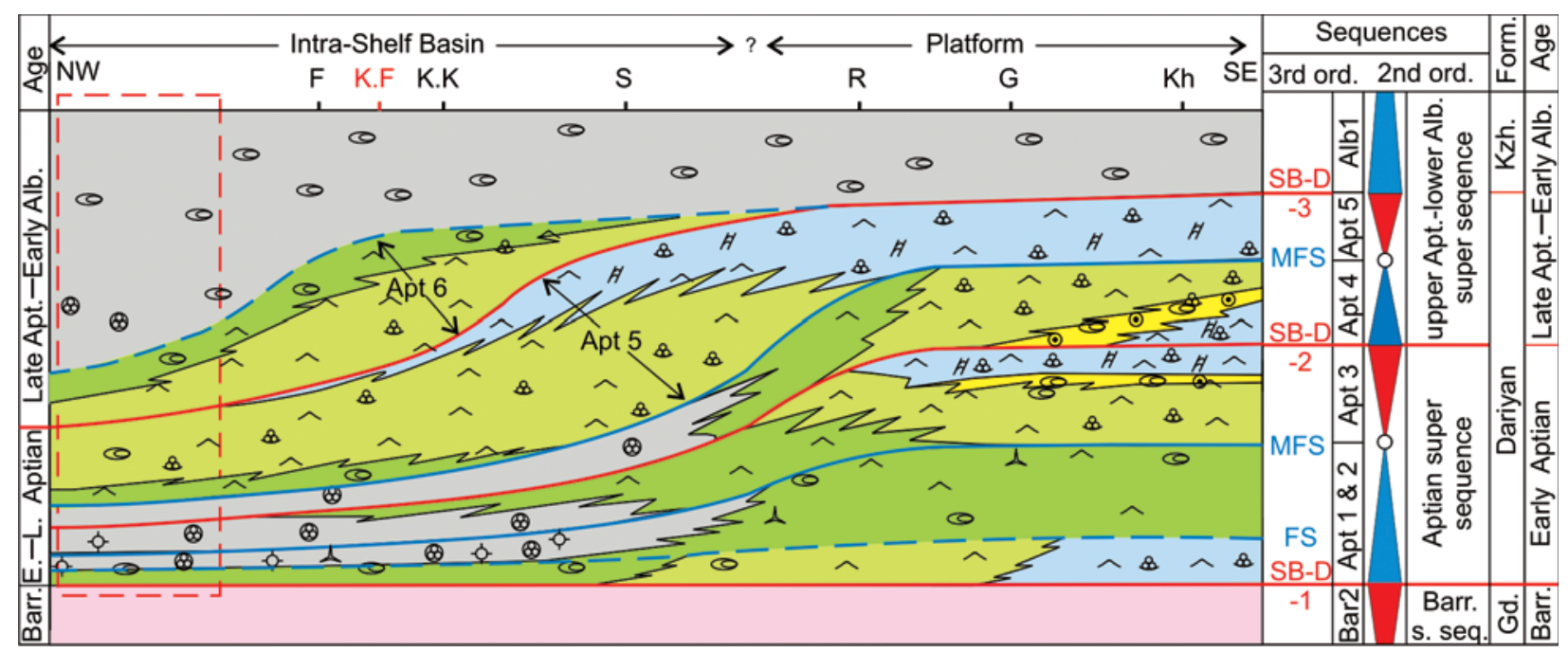

Figure 18. Conceptual sequence-stratigraphic model for the lower Aptian-lower Albian in the study area. The interpretation of the basins (red rectangle) has been based on van Buchem et al. (2010). Abbreviations: F: Kuh-e-Fahliyan, K.K: Kuzeh-Kuh, S: Kuh-e-Sefid, R: Rahmat-Abad, G: Kuh-e-Gadvan Kh: Khaneh-Kat sections. K.F: Kazerun Fault (see Fig. 4 for the legend).

this period of time and it is not possible to correlate the MFS of Apt4 with other parts of the Arabian Plate. This TST is followed by the highstand phase (Apt5) in DS-2.

As mentioned above, at the regional scale, Apt5 is interpreted as the progradation of platform-top sediments towards the intra-shelf basin (van Buchem et al. 2010, Maurer et al. 2012). Due to this progradation, the mid-late Aptian orbitolinid-rich sediments were deposited in intra-shelf basin and green algae/benthic foraminifers facies were extended to the platform settings (Apt5). This facies change is interpreted as a highstand systems tract at the local and lowstand systems tract at the regional scale. Like Apt4, the sediments of Apt5 have been recorded in all the six studied sections (based on presence of the Mesorbitolina texana Zone) but not in the southwestern parts of the Arabian Plate such as Coastal Fars (Iran), Oman, UAE and Qatar (e.g. van Buchem 2010). Indeed, the relatively shallow water facies of Apt5 observed in both platform and margin of intra-shelf basin settings (only in Interior Fars Province and Izeh Zone) reflect a slowdown of the basin subsidence and the accommodation rates (Fig. 18).

During the end of the late Aptian the platform was emerged and the sedimentation was limited to the margin of intra-shelf basin (Fig. 19C). The top boundary of Apt5 showed a hiatus in the platform sections as indicated by the absence of Mesorbitolina subconcava and Hemicyclammina sigali, whereas in the intra-shelf basin sections Apt5 is followed by Apt6 (Figs 18, 19C). This has been related to the late Aptian sea-level fall (Schroeder et al. 2010, van Buchem et al. 2010, Maurer et al. 2012). This coincided with the late Aptian regressive phase recorded on the Arabian Plate, where the sea-level fall led to subaerial exposures in most parts of the platform and re- stricted the sediment depositions in to the intra-shelf basins (e.g. Bab and Kazhdumi basins; Schroeder et al. 2010, van Buchem et al. 2010). In the interior Fars Province of the High Zagros area, no direct sedimentary evidence for subaerial exposure has been observed (van Buchem et al. 2010) but the biostratigraphic data and the sequence stratigraphy analysis of the Arabian Plate (Sharland et al. 2001, Zigler 2001, van Buchem et al. 2010) prove the presence of a hiatus (Fig. 19C). In the coastal Fars area, the sections Kuh-e-Asaluyeh and Kuh-e-Gach recorded the exposure surface as paleosol horizons on top surface of Apt3 (van Buchem et al. 2010) and it characterized by pervasive karstification and the formation of iron crust on the top surface of the Shuaiba Formation in southern parts of Arabian Plate (Rameil et al. 2012). The late Aptian sea level fall and the subsequent lowstand systems tract have been observed worldwide. In the Russian Platform and in western Siberia, this was characterized by pervasive erosion on the top of the platform (Sahagian et al. 1996) and incised valleys (Medvedev et al. 2011). More evidence of coeval exposure has also been reported from Portugal (Heimhofer et al. 2007) and Spain (Rodriguez Lopez et al. 2008), showing that the western parts of the Neo-Tethys margin were subaerially exposed during this period of time. Given the widespread lowstand deposits and the "cooling pulses" evidenced by the oxygen isotopes (Maurer et al. 2012) during the late Aptian, a glacio-eustatic control on sea-level variations was proposed by Maurer et al. (2012) as the most likely cause for the sea-level fall in the late Aptian due to the fast ice cap growth. The rise in sea level during the late late Aptian-early Albian led to deposition of Apt6 on the margin of intra-shelf basin but not on the top-platform part (Figs 18, 19D). The presence of Apt6 indicates the uninter- 

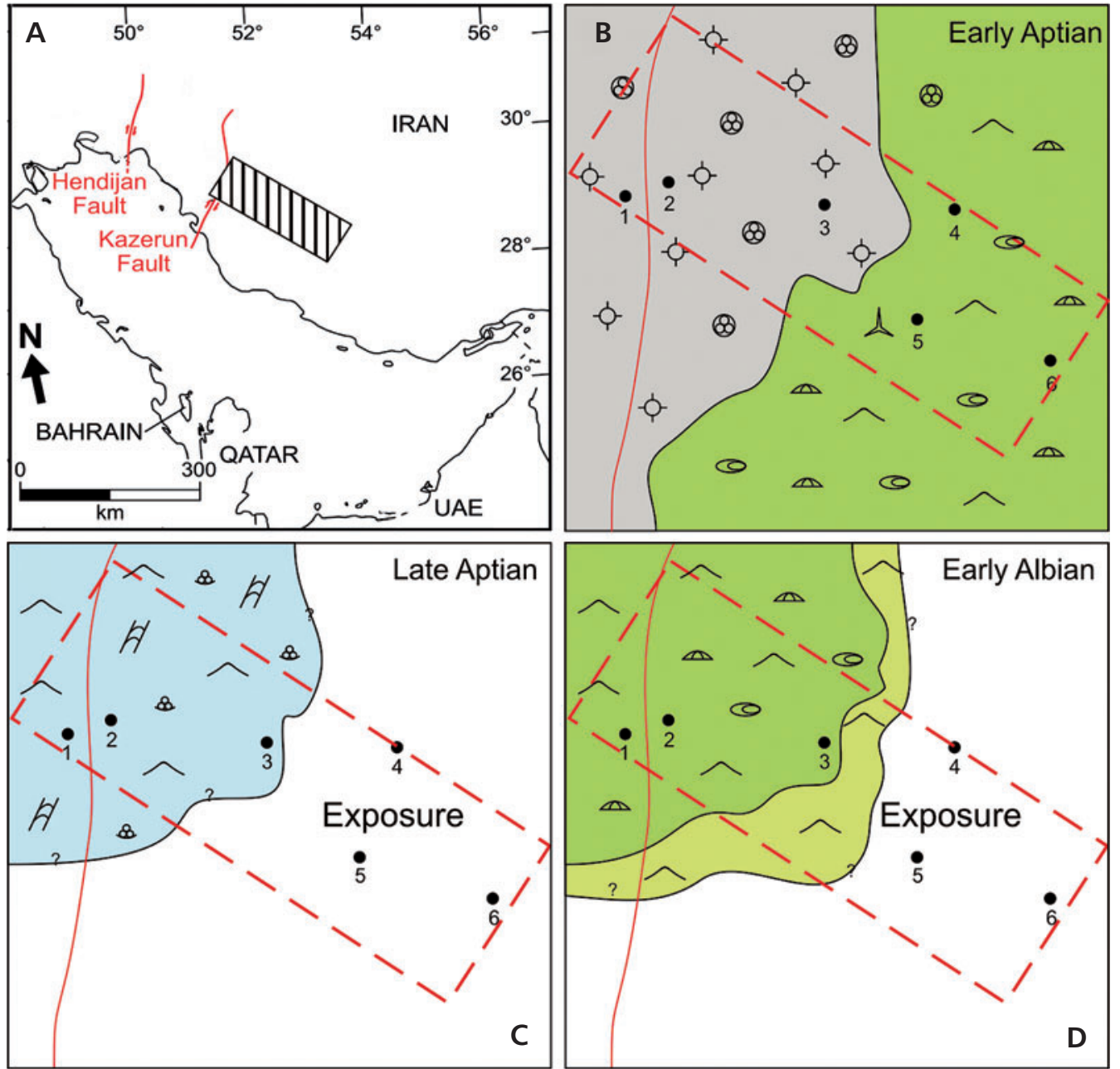

Figure 19. Paleogeographic maps showing distribution of the facies belts in the study area. $\bullet A-$ general location map of southwest Iran. $\bullet B-$ late early Aptian MFS. $\bullet$ C - late Aptian HST and exposure of shallow platform parts. $\bullet$ D - late late Aptian-early Albian TST. The red line indicates the position of the Kazerun Fault. 1 - Kuh-e-Fahliyan; 2 - Kuzeh-Kuh; 3 - Kuh-e-Sefid; 4 - Rahmat-Abad; 5 - Kuh-e-Gadvan; 6 - Khaneh-Kat sections (see Fig. 4 for the legend).

rupted record of late Aptian-early Albian sediments on margin of intra-shelf basin setting. The distribution of facies belts has been shown in the paleogeographic map (Fig. 19).

\section{Conclusions}

The microfacies analysis and the sedimentological study of the Dariyan Formation in the Interior Fars Province and Izeh Zone show fifteen different types of facies, which can be regrouped into four facies associations, which characterize four depositional environments (lagoon, shoal, shallow and deep open marine) in a homoclinal carbonate ramp to margin of intra-shelf basin setting. Based on the sequence stratigraphy analysis, this formation has been divided into three $2^{\text {nd }}$-order depositional sequences, which include six $3^{\text {rd }}$-order sequences. The eustatic sea-level variations have been identified as the main cause of early Aptian sea-level rise and the late Aptian sea level fall. The lateral distribution of microfacies and sequence stratigraphic interpretations reveal the extension of intra-shelf basin sediments to the Interior Fars Province indicating that the subsidence of the Kazerun Fault was related to other fault systems and/or movements of infra-Cambrian Hormuz Salt. This led to the large areas of subsidence. As shown by the biostratigraphic data, facies similarity and the sequence stratigraphic analysis, the middle shale of the Dariyan Formation is genetically related to the Kazhdumi Basin sediments. Therefore, this interval could be named informally "Kazhdumi Tongue". The fossil contents of the Dariyan Formation suggest that there is a stratigraphic hiatus in the platform parts, where no sediments may have been deposited due to the late Aptian sea level fall. Nevertheless, no clear sedimentary evidence has been found for subaerial exposure in the study area. 


\section{Acknowledgments}

The authors are grateful and would like to thank F. van Buchem (Maersk Oil, Copenhagen) for manuscript revision and constructive comments and also S. Westermann (Bristol University) for editing of the text. Many thanks also to Mr. Moosavi, Mr. Hoseyni and Mr. Najibi for their help in the field. We also wish to express our gratitude to M. Wilmsen (Dresden), S. Abolfazl Hosseini (Tehran) and an anonymous reviewer for their critical comments and help offered to bring this work in its final form. Financial support from the Ferdowsi University of Mashhad, Iran, is gratefully acknowledged.

\section{References}

Al-Fares, A.A., Bouman, M. \& Jeans, P. 1998. A new look at the Lower to Middle Cretaceous stratigraphy, offshore Kuwait. GeoArabia 3, 543-560.

AL-GamDi, N.M. 2006. Facies, sequence framework and evolution of rudist buildups, Shuaiba Formation, Saudi Arabia. 87 pp. M.Sc. thesis, Blacksburg, Virginia, USA.

AfZal, J., Williams, M., Leng, M.J. \& Aldridge, R.J. 2011. Dynamic response of the shallow marine benthic ecosystem to regional and pan-Tethyan environmental change at the Paleocene-Eocene boundary. Palaeogeography, Palaeoclimatology, Palaeoecology 309, 141-160.

DOI 10.1016/j.palaeo.2011.04.005

ALAVI, M. 1980. Tectonostratigraphic evolution of the Zagrosides of Iran. Geology 8, 144-149. DOI 10.1130/0091-7613(1980)8<144:TEOTZO >2.0.CO;2

Alavi, M. 1994. Tectonics of the Zagros orogenic belt of Iran: new data and interpretations. Tectonophysics 229, 211-238. DOI 10.1016/0040-1951(94)90030-2

Alavi, M. 2004. Regional stratigraphy of the Zagros fold-thrust belt of Iran and its proforeland evolution. American Journal of Science 304, 1-20. DOI 10.2475/ajs.304.1.1

Alavi, M. 2007. Structures of the Zagros fold-thrust belt in Iran. American Journal of Science 307, 1064-1095. DOI 10.2475/09.2007.02

Armella, C., Cabaleri, N.G., Cagnoni, M.C. \& Panarello, H.O. 2013. Early Callovian ingression in southwestern Gondwana. Palaeoenvironmental evolution of the carbonate ramp (Calabozo Formation) in southwestern Mendoza, Neuquen basin, Argentina. Journal of South American Earth Sciences 45, 293-315. DOI 10.1016/j.jsames.2013.03.013

AzZAM, I.N. \& TAHER, A.K. 1995. Sequence stratigraphy and source rock potential of Aptian (Bap Member) in east offshore Abu Dhabi: A model approach to oil exploration. Proceedings of the Society of Petroleum Engineers $9^{\text {th }}$ Middle East Oil Show, Paper SPE 29802, 305-317.

BaChmann, M. \& HiRsCh, F. 2006. Lower Cretaceous carbonate platform of the eastern Levant (Galilee and the Golan Heights): stratigraphy and second-order sea-level change. Cretaceous Research 27, 487-512. DOI 10.1016/j.cretres.2005.09.003

BASSI, D. 2005. Larger foraminiferal and coralline algal facies in an Upper Eocene storm-influenced, shallow-water carbonate platform (Colli Berici, north-eastern Italy). Palaeogeography, Palaeoclimatology, Palaeoecology 226, 17-35.

DOI 10.1016/j.palaeo.2005.05.002

Bassi, D. \& Nebelsick, J.H. 2010. Components, facies and ramps: redefining Upper Oligocene shallow water carbonates using coralline red algae and larger foraminifera (Venetian area, northeast Italy). Palaeogeography, Palaeoclimatology, Palaeoecology 295, 258-280.

DOI 10.1016/j.palaeo.2010.06.003

Berberian, M. \& King, G. 1981. Towards a paleogeography and tectonic evolution of Iran. Canadian Journal of Earth Sciences 18, 210-265. DOI 10.1139/e81-019

Bordenave, M.L. \& Burwood, R. 1990. Source rock distribution and maturation in the Zagros orogenic belt, Provenance of the Asmari and Sarvak reservoir oil accumulation. Organic Geochemistry 16, 369-387.

DOI 10.1016/0146-6380(90)90055-5

Bover-Arnal, T., Salas, R., Moreno-Bedmar, J.A. \& Bitzer, K. 2009. Sequence stratigraphy and architecture of a late Early-Middle Aptian carbonate platform succession from the western Maestrat Basin (Iberian Chain, Spain). Sedimentary Geology 219, 280-301. DOI 10.1016/j.sedgeo.2009.05.016

Burchette, T. \& Wright, V. 1992. Carbonate ramp depositional systems. Sedimentary Geology 79, 3-57. DOI 10.1016/0037-0738(92)90003-A

Calavan, C.W., Hagerty, R.M., Mitchell, J.C. \& Schutter, S.R. 1992. Integrated Reservoir and Modeling of the Shuaiba Reservoir, Bu Hasan Field, Abu Dhabi, U.A.E. Proceedings of the Society of Petroleum Engineers $5^{\text {th }}$ Abu Dhabi Petroleum Conference, Paper SPE 24509, 299-312.

Cantalamessa, G., Di Celma, C. \& Ragaini, L. 2006. Tectonic controls on sequence stacking pattern and along-strike architecture in the Pleistocene Mejillones Formation, northern Chile: implications for sequence stratigraphic models. Sedimentary Geology 183, 125-144.

DOI 10.1016/j.sedgeo.2005.09.010

Catuneanu, O. 2006. Principle of Sequence Stratigraphy. 386 pp. Elsevier, New York.

Catuneanu, O., Abreu, V., Bhattacharya, J., Blum, M., Dalrymple, R., Eriksson, P., Fielding, C.R., Fisher, W., GalloWAY, W. \& GibLinG, M. 2009. Towards the standardization of sequence stratigraphy. Earth-Science Reviews 92, 1-33. DOI 10.1016/j.earscirev.2008.10.003

Chatalov, A. 2013. A Triassic homoclinal ramp from the Western Tethyan realm, Western Balkanides, Bulgaria: Integrated insight with special emphasis on the Anisian outer to inner ramp facies transition. Palaeogeography, Palaeoclimatology, Palaeoecology 386, 34-58.

DOI 10.1016/j.palaeo.2013.04.028

Corda, L. \& Brandano, M. 2003. Aphotic zone carbonate production on a Miocene ramp, Central Apennines, Italy. Sedimentary Geology 161, 55-70.

DOI 10.1016/S0037-0738(02)00395-0

Cosovic, V., Drobne, K. \& Moro, A. 2004. Paleoenvironmental model for Eocene foraminiferal limestones of the Adriatic carbonate platform (Istrian Peninsula). Facies 50, 61-75. DOI 10.1007/s10347-004-0006-9 
Danelian, T., De Wever, P. \& Azéma, J. 1997. Palaeoceanographic significance of new and revised palaeontological datings for the onset of Vigla Limestone sedimentation in the Ionian Zone of Greece. Geological Magazine 134, 869-872. DOI 10.1017/S0016756897007553

Davies, R.B., Casey, D.M., Horbury, A.D., Sharland, P.R. \& Simmons, M.D. 2002. Early to mid-Cretaceous mixed carbonate-siliciclastic shelfal systems: examples, issues and models from the Arabian plate. GeoArabia 7, 541-598.

Dickson, J.A.D. 1966. Carbonate identification and genesis as revealed by staining. Journal of Sedimentary Research 36, 441-505.

Droste, H. 1990. Depositional cycles and source rock development in an epeiric intraplatform basin: The Hanifa Formation of the Arabian Peninsula. Sedimentary Geology 69, 281-296. DOI 10.1016/0037-0738(90)90054-W

DuNHAM, R.J. 1962. Classification of carbonate rocks according to depositional texture, 108-121. In HAM, W.E. (ed.) Classification of Carbonate Rocks. American Assocciation of Petroleum Geologists Memoir 1.

Elkhazri, A., Abdallah, H., Razgallah, S., Moullade, M. \& KuHNT, W. 2012. Carbon-isotope and microfaunal stratigraphy bounding the Lower Aptian Oceanic Anoxic Event 1a in northeastern Tunisia. Cretaceous Research 39, 133-148. DOI 10.1016/j.cretres.2012.05.011

Ellis, G. \& Baumgartner, P. 1995. Austral shallow-water radiolarites - implications for the global cycling of silicon and carbon in the Mid-Cretaceous. European Union of Geosciences 8, 225 .

Embry, A.F. \& Klovan, J.E. 1971. A late Devonian reef tract on northeastern Banks Island, NWT. Bulletin of Canadian Petroleum Geology 19, 730-781.

Frakes, L.A., Francis, J.E. \& Syktus, J.I. 2005. Climate modes of the Phanerozoic. 182 pp. Cambridge University Press, Cambridge University Press.

FLÜGEL, E. 2010. Microfacies of carbonate rocks: analysis, interpretation and application. 984 pp. Springer Verlag, Berlin. DOI 10.1007/978-3-642-03796-2

Galloway, W.E. 1989. Genetic stratigraphic sequences in basin analysis I: architecture and genesis of flooding-surface bounded depositional units. American Assocciation of Petroleum Geologists Bulletin 73, 125-142.

Ghabeishavi, A., Vaziri-Moghaddam, H., Taheri, A. \& TaAti, F. 2010. Microfacies and depositional environment of the Cenomanian of the Bangestan Anticline, SW Iran. Journal of Asian Earth Sciences 37, 275-285. DOI 10.1016/j.jseaes.2009.08.014

Gharsalli, R., Zouaghi, T., Soussi, M., Chebbi, R., Khomsi, S. \& BEDIR, M. 2013. Seismic sequence stratigraphy of Miocene deposits related to eustatic, tectonic and climatic events, Cap Bon Peninsula, northeastern Tunisia. Comptes Rendus Geoscience 345(9-10), 401-417.

DOI 10.1016/j.crte.2013.07.003

Gorican, S., Pavsic, J. \& Rozic, B. 2012. Bajocian to Tithonian age of radiolarian chert in the Tolmin basin (NW Slovenia). Bulletin de la Société Géologique de France 183, 369-382. DOI 10.2113/gssgfbull.183.4.369
Grotsch, J., Billing, I. \& VAhrenkamp, V. 1998. Carbon-isotope stratigraphy in shallow-water carbonates: Implications for Cretaceous black-shale deposition. Sedimentology 45, 623-634. DOI 10.1046/j.1365-3091.1998.00158.x

HaQ, B.U., Hardenbol, J. \& Vail, P.R. 1988. Mesozoic and Cenozoic chronostratigraphy and cycles of sea-level change. Society of Economic Palaeontologists and Mineralogists Special Publication 42, 71-108.

Heldt, M., Lehmann, J., Bachmann, M., Negra, H. \& Kuss, J. 2010. Increased terrigenous influx but no drowning: palaeoenvironmental evolution of the Tunisian carbonate platform margin during the Late Aptian. Sedimentology 57, 695-719. DOI 10.1111/j.1365-3091.2009.01115.x

Hu, X., Zhao, K., Yilmaz, I.O. \& Li, Y. 2012. Stratigraphic transition and palaeoenvironmental changes from the Aptian oceanic anoxic event 1a (OAE1a) to the oceanic red bed 1 (ORB1) in the Yenicesihlar section, central Turkey. Cretaceous Research 38, 40-51. DOI 10.1016/j.cretres.2012.01.007

Heimhofer, U., Hochuli, P.A., Burla, S. \& Weissert, H. 2007. New records of Early Cretaceous angiosperm pollen from Portuguese coastal deposits: implications for the timing of the early angiosperm radiation. Review of Palaeobotany and Palynology 144, 39-76.

DOI 10.1016/j.revpalbo.2005.09.006

HEYDARI, E. 2008. Tectonics versus eustatic control on supersequences of the Zagros Mountains of Iran. Tectonophysics 451, 56-70. DOI 10.1016/j.tecto.2007.11.046

Huck, S., Rameil, N., Korbar, T., Heimhofer, U., Wieczorek, T.D. \& Immenhauser, A. 2010. Latitudinally different responses of Tethyan shoal-water carbonate systems to the Early Aptian oceanic anoxic event (OAE 1a). Sedimentology 57, 1585-1614. DOI 10.1111/j.1365-3091.2010.01157.x

Hughes, G. 2000. Saudi Arabian Late Jurassic and Early Cretaceous agglutinated foraminiferal associations and their application for age, palaeoenvironmental interpretation, sequence stratigraphy, and carbonate reservoir architecture. Grzybowski Foundation Special Publication 7, 149-165.

Jahani, D., Peyman, F. \& Jamali, A. 2009. Facies analysis and sedimentary environment of the Gadvan Formation in the Kuzeh-Kuh Anticline, Northeast of Nurabad. Journal of Sediment and Sedimentary Rock 2, 1-12.

JAMES, G. \& WYND, J. 1965. Stratigraphic nomenclature of Iranian oil consortium agreement area. American Assocciation of Petroleum Geologists Bulletin 49, 2182-2245.

JENKYNS, H.C. 2010. Geochemistry of oceanic anoxic events. Geochemistry Geophysics Geosystems 11(3), Q03004. DOI 10.1029/2009GC002788

Khalifa, M.A., Abu El-Ghar, M.S., Helal, S.A. \& Hussein, A.W. 2013. Sequence stratigraphy of the Cenomanian Galala Formation, north Eastern Desert, Egypt. Journal of African Earth Sciences 89, 133-148. DOI 10.1016/j.jafrearsci.2013.09.005

LAYA, J.C. \& Tucker, M.E. 2012. Facies analysis and depositional environments of Permian carbonates of the Venezuelan Andes: Palaeogeographic implications for Northern Gondwana. Palaeogeography, Palaeoclimatology, Palaeoecology 331, 1-26. DOI 10.1016/j.palaeo.2012.02.011 
Leckie, R.M., Bralower, T.J. \& Cashman, R. 2002. Oceanic anoxic events and plankton evolution: Biotic response to tectonic forcing during the mid-Cretaceous. Paleoceanography 17, 10-41. DOI 10.1029/2001PA000623

Lü, C., Wu, S., Yao, Y. \& Fulthorpe, C.S. 2013. Development and controlling factors of Miocene carbonate platform in the Nam Con Son Basin, southwestern South China Sea. Marine and Petroleum Geology 45, 55-68.

DOI 10.1016/j.marpetgeo.2013.04.014

MANCINELLI, A. 2006. Acroporella cairensis n. sp. (Dasycladales) from the Barremian of Monte Cairo (southern Latium, Italy). Facies 52, 411-416. DOI 10.1007/s10347-006-0047-3

Masse, J.P. 1993. Valanginian-early Aptian carbonate platforms from Provence, southeastern France. American Association of Petroleum Geologists Memoir 56, 363-374.

Masse, J.P., Fenerci, M. \& Pernarcic, E. 2003. Palaeobathymetric reconstruction of peritidal carbonates: Late Barremian, Urgonian sequences of Provence (SE France). Palaeogeography, Palaeoclimatology, Palaeoecology 200, 65-81. DOI 10.1016/S0031-0182(03)00445-0

Matthews, R.K. \& Frohlich, C. 2002. Maximum flooding surfaces and sequence boundaries: comparisons between observations and orbital forcing in the Cretaceous and Jurassic (65-190 Ma). GeoArabia 7, 502-538.

Maurer, F., Al-Mehsin, K., Pierson, B.J., Eberli, G.P., WarrLich, G., Drysdale, D. \& Droste, H.J. 2010. Facies characteristics and architecture of Upper Aptian Shu' aiba clinoforms in Abu Dhabi. GeoArabia 2, 445-468.

Maurer, F., van Buchem, F.S., Eberli, G.P., Pierson, B.J., RAven, M.J., Larsen, P.H., Al-Husseini, M.I. \& Vincent, B. 2012. Late Aptian long-lived glacio-eustatic lowstand recorded on the Arabian Plate. Terra Nova 25(2), 87-94. DOI 10.1111/ter.12009

Medvedev, A.L., Lopatin, A.Y. \& Masalkin, Y.V. 2011. Comparative characteristics of the lithological composition of the incised valley fill and host sediments of the Vikulovo Formation, Kamenny Area, West Siberia. Lithology and Mineral Resources 46(4), 369-381. DOI 10.1134/S0024490211040067

Mehay, S., Keller, C.E., Bernasconi, S.M., Weissert, H., Erba, E., Bottini, C. \& Hochuli, P.A. 2009. A volcanic $\mathrm{CO}_{2}$ pulse triggered the Cretaceous Oceanic Anoxic Event 1a and a biocalcification crisis. Geology 37, 819-822. DOI 10.1130/G30100A.1

Moosavizadeh, M.A., Mahboubi, A., Moussavi-Harami, R. \& Kavoosi, M.A. 2013 (in press). Early Aptian oceanic anoxic event (OAE 1a) in Northeastern Arabian Plate setting: an example from Dariyan Formation in Zagros fold-thrust belt, SE Iran. Arabian Journal of Geosciences. DOI $10.1007 / \mathrm{s} 12517-013-1025-\mathrm{z}$

MotieI, H. 1993. Treatise of geology of Iran 1. Stratigraphy of Zagros. 536 pp. Iran Geological Survey Publication, Tehran. [in Persian]

Navabpour, P., Angelier, J. \& Barrier, E. 2010. Mesozoic extensional brittle tectonics of the Arabian passive margin, inverted in the Zagros collision (Iran, interior Fars), 65-96. In Leturmy, P. \& Robin, C. (eds) Tectonic and Stratigraphy Evolution of Zagros and Makran during the Mesozoic-Ceno- zoic. Geological Society of London, Special Publications 330.

NAZARIYAN, M. 2007. Microfacies, sedimentary environment and sequence stratigraphy of Dariyan Formation in Sivand and Dashtak sections. 147 pp. M.Sc. thesis, Islamic Azad University, Tehran.

Palma, R.M., Lopez-Gomez, J. \& Piethe, R.D. 2007. Oxfordian ramp system (La Manga Formation) in the Bardas Blancas area (Mendoza Province) Neuquén Basin, Argentina: Facies and depositional sequences. Sedimentary Geology 195, 113-134. DOI 10.1016/j.sedgeo.2006.07.001

Payros, A. \& Pujalte, V. 2008. Calciclastic submarine fans: An integrated overview. Earth-Science Reviews 86, 203-246. DOI 10.1016/j.earscirev.2007.09.001

Payros, A., Pujalte, V., Tosquella, J. \& Orue-Etxebarria, X. 2010. The Eocene storm-dominated foralgal ramp of the western Pyrenees (Urbasa-Andia Formation): An analogue of future shallow-marine carbonate systems? Sedimentary Geology 228, 184-204. DOI 10.1016/j.sedgeo.2010.04.010

PenNey, S.J. \& Racey, A. 2004. Ecology of extant nummulitids and other larger benthic foraminifera: applications in palaeoenvironmental analysis. Earth-Science Reviews 67, 219-265. DOI 10.1016/j.earscirev.2004.02.005

Pérez-López, A. \& Pérez-Valera, F. 2012. Tempestite facies models for the epicontinental Triassic carbonates of the Betic Cordillera (southern Spain). Sedimentology 59(2), 646-678. DOI 10.1111/j.1365-3091.2011.01270.x

Peyman, F., Jahani, D., Jamali, A.M. \& Kavoosi, M.A. 2010. Eustasy and tectonic control on facies and sedimentary environment of Upper Khami deposits in East and West Kazerun fault, SW Iran. International Applied Geological Congress, Department of Geology, Islamic Azad University - Mashad Branch, Iran, 26-28 April, 1509-1514.

Piryaei, A., Reijmer, J., Borgomano, J. \& van Buchem, F. 2011. Late Cretaceous tectonic and sedimentary evolution of the Bandar Abbas area, Fars region, southern Iran. Journal of Petroleum Geology 34(2), 157-180. DOI 10.1111/j.1747-5457.2011.00499.x

Piryaei, A., ReiJmer, J.J.G., van Buchem, F.S.P., YaZdi-Moghadam, M., Sadouni, J. \& Danelian, T. 2010. The influence of Late Cretaceous tectonic processes on sedimentation patterns along the northeastern Arabian plate margin (Fars Province, SW Iran), 211-251. In Leturmy, P. \& Robin, C. (eds) Tectonic and Stratigraphy Evolution of Zagros and Makran during the Mesozoic-Cenozoic. Geological Society of London, Special Publications 330.

Pittet, B., van Buchem, F.S.P., Hillgärtner, H., Razin, P., Grötsch, J. \& Droste, H. 2002. Ecological succession, palaeoenvironmental change, and depositional sequences of Barremian-Aptian shallow-water carbonates in northern Oman. Sedimentology 49, 555-581. DOI 10.1046/j.1365-3091.2002.00460.x

Pomar, L. 2001. Types of carbonate platforms: a genetic approach. Basin Research 13, 313-334. DOI 10.1046/j.0950-091x.2001.00152.x

Pomar, L., Bassant, P., Brandano, M., Ruchonnet, C. \& JanSON, X. 2012. Impact of carbonate producing biota on platform 
architecture: Insights from Miocene examples of the Mediterranean region. Earth-Science Reviews 113, 186-211. DOI 10.1016/j.earscirev.2012.03.007

Rameil, N., Immenhauser, A., Csoma, A.É. \& Warrlich, G. 2012. Surfaces with a long history: the Aptian top Shu'aiba Formation unconformity, Sultanate of Oman. Sedimentology 59(1), 212-248. DOI 10.1111/j.1365-3091.2011.01279.x

Raven, M.J., van Buchem, F.S.P., Larsen, P.H., Surlyk, F., Steinhardt, H., Cross, D., Klem, N. \& Emang, M. 2010. Late Aptian incised valleys and siliciclastic infill at the top of Shuaiba Formation (Block 5, offshore Qatar). GeoArabia, Special Publication 4, 469-502.

Razin, P., TaAti, F. \& van Buchem, F.S.P. 2010. Sequence stratigraphy of Cenomanian-Turonian carbonate platform margins (Sarvak Formation) in the High Zagros, SW Iran: an outcrop reference model for the Arabian Plate. Geological Society of London, Special Publication 329, 187-218. DOI 10.1144/SP329.9

READ, J.F. 1985. Carbonate platform facies models. American Assocciation of Petroleum Geologists Bulletin 69, 1-21.

Rodríguez-López, J.P., Meléndez, N., De Boer, P.L. \& Soria, A.R. 2008. Aeolian sand sea development along the mid-Cretaceous western Tethyan margin (Spain): erg sedimentology and palaeoclimate implications. Sedimentology 55, 1253-1292. DOI 10.1111/j.1365-3091.2007.00945.x

Romero, J., Caus, E. \& Rosell, J. 2002. A model for the palaeoenvironmental distribution of larger foraminifera based on late Middle Eocene deposits on the margin of the South Pyrenean basin (NE Spain). Palaeogeography, Palaeoclimatology, Palaeoecology 179, 43-56. DOI 10.1016/S0031-0182(01)00406-0

Rubert, Y., Jati, M., Loisy, C., Cerepi, A., Foto, G. \& Muska, K. 2012. Sedimentology of resedimented carbonates: Facies and geometrical characterisation of an upper Cretaceous calciturbidite system in Albania. Sedimentary Geology 257, 63-77. DOI 10.1016/j.sedgeo.2012.02.009

SABER, S.G. 2012. Depositional framework and sequence stratigraphy of the Cenomanian-Turonian rocks on the western side of the Gulf of Suez, Egypt. Cretaceous Research 37, 300-318. DOI 10.1016/j.cretres.2012.03.008

SAFARI, F. 2007. Microbiostratigraphy of Dariyan Formation in Dashtak and Sivand sections, Fars area, and correlation with Sarvestan Well-3. 169 pp. M.Sc. thesis, Tehran University, Tehran.

Sahagian, D., Pinous, O., Olferiev, A. \& Zakharov, V. 1996. Eustatic curve for the Middle Jurassic-Cretaceous based on Russian platform and Siberian stratigraphy: zonal resolution. American Assocciation of Petroleum Geologists Bulletin 80, 1433-1458.

SCHLAGER, W. 2005. Carbonate sedimentology and sequence stratigraphy. 208 pp. SEPM, Society for Sedimentary Geology, Oklahoma.

Schroeder, R., van Buchem, F., Cherchi, A., Baghbani, D., VinCent, B., Immenhauser, A. \& Granier, B. 2010. Revised orbitolinid biostratigraphic zonation for the Barremian - Aptian of the eastern Arabian Plate and implications for regional stratigraphic correlations. GeoArabia Special Publication 4, 49-96.
Sedaghat, R. 1982. The sedimentology of the Upper Khami Group, Lower Cretaceous, in East Khuzestan, Southwest Iran. 304 pp. Ph.D. thesis, University of London, London.

Sepenr, M. \& Cosgrove, J. 2004. Structural framework of the Zagros fold-thrust belt, Iran. Marine and Petroleum Geology 21(7), 829-843. DOI 10.1016/j.marpetgeo.2003.07.006

Setudehnia, A. 1976. The Paleozoic sequence at Zard Kuh and Kuh-e-Dinar. Bulletin of the Iranian Petroleum Institute 60, $16-33$.

Sharland, P.R., Archer, R., Casey, D.M., Davies, R.B., Hall, S.H., Heward, A.P., Horbury, A.D. \& Simmons, M.D. 2001. Arabian Plate sequence stratigraphy. GeoArabia, Special Publication 2, 1-371.

Sherkati, S. \& Letouzey, J. 2004. Variation of structural style and basin evolution in the central Zagros (Izeh zone and Dezful Embayment), Iran. Marine and Petroleum Geology 21(5), 535-554. DOI 10.1016/j.marpetgeo.2004.01.007

Simmons, M.D. 1994. Micropalaeontological biozonation of the Kahmah Group (Early Cretaceous), central Oman Mountains, 177-219. In Simmons, M.D. (ed.) Micropalaeontology and Hydrocarbon Exploration in the Middle East. Chapman and Hall, London.

Simmons, M., Whittaker, J. \& Jones, R. 2000. Orbitolinids from Cretaceous sediments of the Middle East - A revision of the FRS Henson and Associates Collection, 411-437. In HART, M.B., Kaminski, M.A. \& Smart, C.W. (eds) Proceedings of the $5^{\text {th }}$ International Workshop on Agglutinated Foraminifera, Grzybowski Foundation Special Publication 7.

Skelton, P.W. \& Gili, E. 2012. Rudists and carbonate platforms in the Aptian: a case study on biotic interactions with ocean chemistry and climate. Sedimentology 59(1), 81-117. DOI 10.1111/j.1365-3091.2011.01292.x

Spengler, A.E. \& ReAd, J.F. 2010. Sequence development on a sediment-starved, low accommodation epeiric carbonate ramp: Silurian Wabash Platform, USA mid-continent during icehouse to greenhouse transition. Sedimentary Geology 224, 84-115. DOI 10.1016/j.sedgeo.2009.12.008

Tomas, S., Loser, H. \& SAlas, R. 2008. Low-light and nutrient-rich coral assemblages in an Upper Aptian carbonate platform of the southern Maestrat Basin (Iberian Chain, eastern Spain). Cretaceous Research 29, 509-534. DOI 10.1016/j.cretres.2007.09.001

Vail, P., Audemard, F., Bowman, S. \& Eisner, P. 1991. The stratigraphic signatures of tectonics, eustasy and sedimentology - an overview, 617-659. In EINSLE, G., RicKEN, W. \& SeIlacher, A. (eds) Cycles and Events in Stratigraphy. Springer-Verlag, Berlin, Heidelberg, New York.

van Buchem, F.S.P., Baghbani, D., Bulot, L.G., Caron, M., Gaumet, F., Hosseini, A., Keyvani, F., Schroeder, R., Swennen, R. \& Vedrenne, V. 2010. Barremian-Lower Albian sequence stratigraphy of southwest Iran (Gadvan, Dariyan and Kazhdumi formations) and its comparison with Oman, Qatar and the United Arab Emirates, Barremian-Aptian stratigraphy and hydrocarbon habitat of the eastern Arabian Plate. GeoArabia Special Publication 4, 503-548.

van Buchem, F., Pittet, B., Hillgarten, H., Grotsch, J., Al-Mansouri, A., Billing, I., Droste, H., Oterdoom, H. \& 
van STEenwinkel, M. 2002. High-resolution sequence stratigraphic architecture of the Barremian-Aptian carbonate systems in northern Oman and the United Arab Emirates Kharaib and Shu'aiba Formations. GeoArabia 7, 461-500.

van Wagoner, J., Mitchum, R., Campion, K. \& Rahmanian, V. 1990. Siliciclastic sequence stratigraphy in well logs, cores, and outcrops: Concept of high-resolution correlation of time and facies. American Assocciation of Petroleum Geologists Bulletin, Methods in Exploration 7, 55.

van Wagoner, J., Posamentier, H., Mitchum, R., Vail, P., SARG, J., Loutit, T. \& Hardenbol, J. 1988. An overview of the fundamentals of sequence stratigraphy and key definitions, 39-45. In Wilgus, C.K., Posamentier, H., Hastings, B.S., van Wagoner, J., Ross, C.A. \& Kendall, C.G.S.C. (eds) Sea-level changes - an integrated approach. SEPM Special Publication 42. DOI 10.2110/pec.88.01.0039

Vaziri-Moghaddam, H., Kimiagari, M. \& Taheri, A. 2006. Depositional environment and sequence stratigraphy of the Oligo-Miocene Asmari Formation in SW Iran. Facies 52, 41-51. DOI 10.1007/s10347-005-0018-0

Weissert, H. \& Erba, E. 2004. Volcanism, $\mathrm{CO}_{2}$ and palaeoclimate: a Late Jurassic-Early Cretaceous carbon and oxygen isotope record. Journal of the Geological Society 161(4), 695-702. DOI 10.1144/0016-764903-087
Weissert, H., Lini, A., Föllmi, K.B. \& Kuhn, O. 1998. Correlation of Early Cretaceous carbon isotope stratigraphy and platform drowning events: a possible link. Palaeogeography, Palaeoclimatology, Palaeoecology 137, 189-203.

DOI 10.1016/S0031-0182(97)00109-0

WiLSON, J.L. 1975. Carbonate Facies in Geologic History. 471 pp. Springer, New York. DOI 10.1007/978-1-4612-6383-8

WITT, W. \& GöKDAG, H. 1994. Orbitolinid biostratigraphy of the Shuaiba Formation (Aptian), Oman-Implications for reservoir development, 221-234. In Simmons, M.D. (ed.) Micropalaeontology and Hydrocarbon Exploration in the Middle East. Chapman and Hall, London.

Yose, L.A., Ruf, A.S., Strohmenger, C.J., SchuelKe, J.S., Gombos, A., Al-Hosani, I., Al-Maskary, S., Bloch, G., Al-Mehairi, Y. \& Johnson, I.G. 2006. Three dimensional characterization of a heterogeneous carbonate reservoir, Lower Cretaceous, Abu Dhabi (United Arab Emirates), 173-212. In Harris, P.M. \& WEBER, L.J. (eds) Giant Hydrocarbon Reservoirs of the World: From Rock to Reservoir Characterization and Modeling. American Association of Petroleum Geologists Memoir 88.

ZiEgLER, M.A. 2001. Late Permian to Holocene paleofacies evolution of the Arabian Plate and its hydrocarbon occurrences. GeoArabia 6, 445-504. 